\title{
Lingulodinium machaerophorum expansion over the last centuries in the Caspian Sea reflects global warming
}

\author{
S. A. G. Leroy ${ }^{1}$, H. A. K. Lahijani ${ }^{2}$, J.-L. Reyss ${ }^{3}$, F. Chalié ${ }^{4}$, S. Haghani ${ }^{1,2,5}$, \\ M. Shah-Hosseini ${ }^{2,4}$, S. Shahkarami ${ }^{2,5}$, A. Tudryn $^{6}$, K. Arpe $^{1,7}$, P. Habibi $^{2}$, \\ H. S. Nasrollahzadeh ${ }^{8}$, and A. Makhlough ${ }^{8}$ \\ ${ }^{1}$ Institute for the Environment, Brunel University, Kingston Lane, Uxbridge UB8 3PH, \\ West London, UK \\ ${ }^{2}$ Iranian National Institute for Oceanography (INIO), No 3, Etemadzadeh St., Fatemi Av., \\ Tehran 1411813389, Iran \\ ${ }^{3}$ Laboratoire des Sciences du Climat et de l'Environnement, CEA-CNRS, Avenue de la \\ Terrasse, 91198 Gif-sur-Yvette Cedex, France \\ ${ }^{4}$ Aix-Marseille Université, CEREGE, UMR7330 CNRS, UM34, 13545 Aix-en-Provence \\ cedex 04, France \\ ${ }^{5}$ School of Geology, University of Tehran, Enghelab Sq., Tehran, Iran \\ ${ }^{6}$ Laboratoire CNRS/UPS UMR 8148 IDES, Université de Paris XI, Département des Sciences \\ de la Terre, Bâtiment 504, 91405 ORSAY cedex, France \\ ${ }^{7}$ Max Plank Institute for Meteorology, Hamburg, Germany \\ ${ }^{8}$ Ecology Departments, Caspian Sea Ecology Research Center (CSERC), 961 Sari, Iran
} 16663

Lingulodinium machaerophorum expansion in the Caspian Sea

S. A. G. Leroy et al.

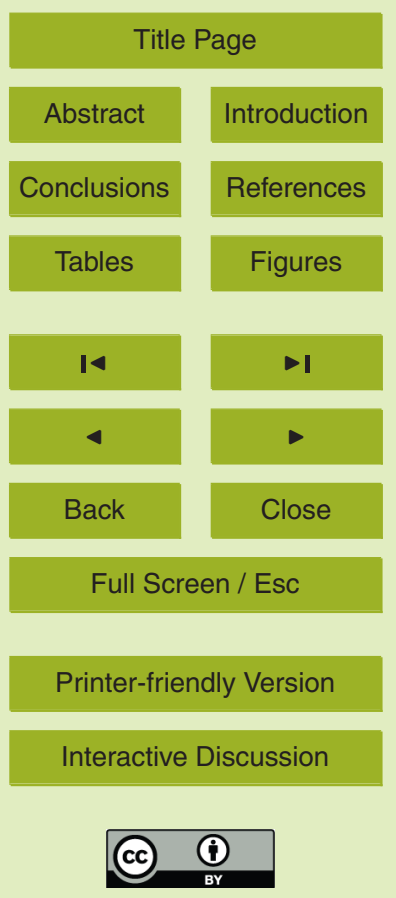


Received: 8 October 2012 - Accepted: 12 November 2012 - Published: 22 November 2012

Correspondence to: S. A. G. Leroy (suzanne.leroy @brunel.ac.uk)

BGD

Published by Copernicus Publications on behalf of the European Geosciences Union.

9, 16663-16704, 2012

Lingulodinium machaerophorum expansion in the Caspian Sea

S. A. G. Leroy et al.

Title Page

Abstract Introduction

Conclusions

References

Tables

Figures

14

$\rightarrow$ I

4

Back

Close

Full Screen / Esc

Printer-friendly Version

Interactive Discussion 


\section{Abstract}

We analysed dinoflagellate cyst assemblages in four short sediment cores, two of them dated by radionuclides, taken in the south basin of the Caspian Sea. The interpretation of the four sequences is supported by a collection of 27 lagoonal or marine surface 5 sediment samples. A sharp increase in the biomass of the dinocyst occurs after 1967, especially owing to Lingulodinium machaerophorum. Considering nine other cores covering parts or the whole of Holocene, this species started to develop in the Caspian Sea only during the last three millennia. By analysing instrumental data and collating existing reconstructions of sea level changes over the last few millennia, we show that for for ing of the incent dinocyst abundance is global climate change, especially sea surface temperature increase. Sea level fluctuations likely have a minor impact. We argue that the Caspian Sea has entered the Anthropocene.

\section{Introduction}

15 The Caspian Sea (CS) is the largest inland water body in the world (Fig. 1). It is well known for the petroleum and caviar it produces. This unique ecosystem with many endemic species is under increasing pressure. The monitoring of its ecosystem changes is inconsistent across the five bordering countries, because of their different socioeconomical level; so an accurate overview of the environmental changes affecting ecosystem processes at present is not available. The instrumental records of the last century indicate rapid changes in sea surface temperature, in sea level and in trophic levels. Sea level changes are large, close to $3 \mathrm{~m}$ amplitude and a hundred times faster than that of the global ocean in the 20th century (Crétaux and Birkett, 2006; Fig. 2a), but also as much as $20 \mathrm{~m}$ amplitude in the last few millennia (Kakroodi et al., 2012). The sea surface temperature of the south basin especially in the summer shows a warming trend over the last century (Ginzburg et al., 2005).
BGD

9, 16663-16704, 2012

\section{Lingulodinium machaerophorum expansion in the Caspian Sea}

S. A. G. Leroy et al.

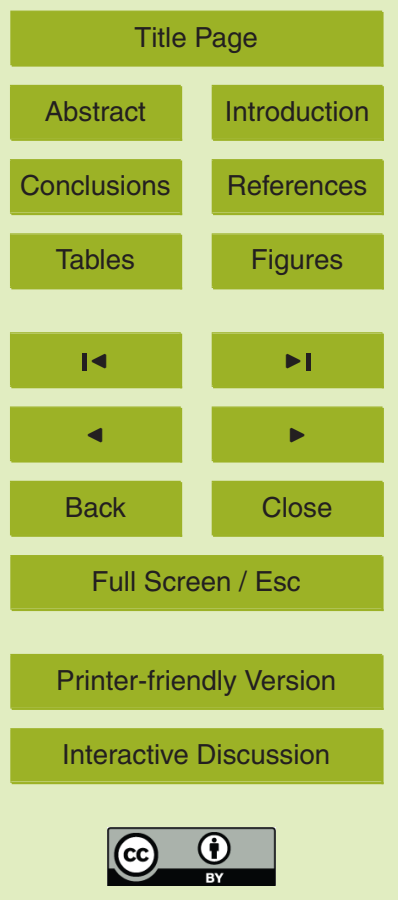


The use of dinocyst-inferred reconstruction of past water parameters, such as temperature, salinity, and nutrient levels, is a powerful palaeoenvironmental approach that may contribute to understanding many of the problems listed above (Marret and Zonneveld, 2003). So far however very few dinocyst analyses are available for recent times 5 in the CS (Leroy et al., 2006, 2011).

Using four short sediment cores (36-166 cm long) and 27 surface samples taken in the south basin and adjacent areas, the aims of this paper are (1) to establish a first spatial distribution pattern of dinoflagellate cysts in the Caspian area, especially the south basin and (2) to detect and explain changes over the last century in dinocyst 10 focus will be on the autotrophic dinocyst Lingulodinium machaerophorum (Deflandre and Cookson, 1955) Wall, 1967, subsequently called $L m$ which is a euryhaline coastal planktonic species restricted to regions with summer temperatures above $10-12^{\circ} \mathrm{C}$ (Marret et al., 2004) and winter temperatures above $0^{\circ} \mathrm{C}$ (Marret and Zonneveld, 2003;

Lewis and Hallett 1997). Its motile form, Lingulodinium polyedra (Stein) Dodge 1989, is reported to cause harmful algal blooms (Howard et al., 2009). This species therefore is sensitive to sea surface temperature and could be used to reflect climatic change in the region.

The impact of this work is important in advancing knowledge of Caspian Sea processes. The Caspian Sea holds a dominant position in the Southwestern Asian region, and is suspected of playing a major part in climate change in this part of the world. However, a lack of a clear understanding of the processes involved in its control such as the North Atlantic Oscillation or the El-Niño Southern Oscillation still exists not only for the last few millennia but also for the last few decades (Arpe et al., 2000, 2012; Arpe and Leroy, 2007). This paper addresses the issue of past temperatures and develops basic data that will underpin future work on Caspian Sea climate-related aspects.

\section{BGD}

9, 16663-16704, 2012

\section{Lingulodinium machaerophorum expansion in the Caspian Sea}

S. A. G. Leroy et al.

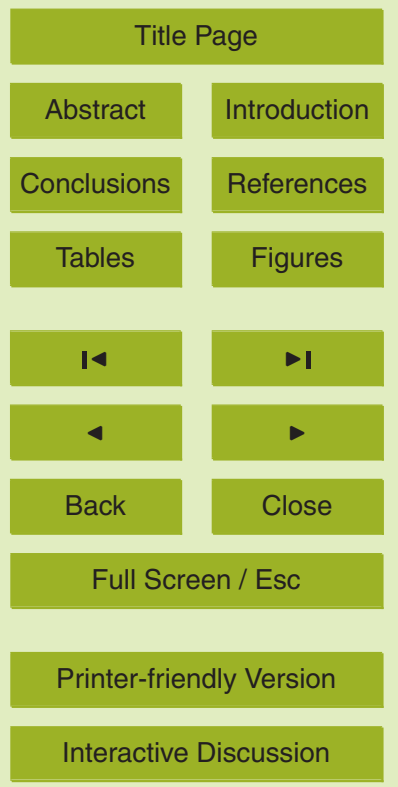




\section{Setting}

\subsection{Geographical setting and climate}

The CS is the world's largest inland water body in terms of both area and volume, extending $35-48^{\circ} \mathrm{N}$ and $47-55^{\circ} \mathrm{E}$. The altitude of the surface lies around $26 \mathrm{mb} . \mathrm{s} . \mathrm{l}$.

5 (25 to 29 mb.s.l. during the last $150 \mathrm{yr}$ ) (Arpe et al., 2012; Leroy et al., 2006). The sea is divided into three basins, becoming deeper southwards: the northern basin $\left(80000 \mathrm{~km}^{2}\right)$ with an average depth of $5 \mathrm{~m}$ and a maximum depth of $15 \mathrm{~m}$; the middle basin $\left(138000 \mathrm{~km}^{2}\right)$ with an average depth of $175 \mathrm{~m}$ and a maximum depth of $788 \mathrm{~m}$; and the Southern basin $\left(168000 \mathrm{~km}^{2}\right)$ with an average depth of $325 \mathrm{~m}$ and a maximum depth of $1025 \mathrm{~m}$. The southern basin holds more than $65 \%$ of the Caspian water.

Because of its great meridional extension $(>1100 \mathrm{~km})$, the CS straddles several climatic zones (Kosarev, 2005). The northern part of the drainage basin lies in a zone of temperate continental climate with the Volga catchment well into the humid midlatitudes. The western coast features a moderately warm climate, while the southwestern and the southern regions fall into a subtropical humid climatic zone. The eastern coast has a desert climate.

\subsection{Currents, salinity and temperature}

A complex sea current pattern in the middle and south basins is dominated by a surface cyclonic gyre (Zenkevitch, 1963). Specifically in the South Caspian a dipole system, consisting of an anticyclonic gyre in its northwestern part and a cyclonic gyre in its southeastern part, exists throughout the year (Zaker et al., 2011). The sea currents influence the four studied sites as they have potential to transport fine-grained materials. In contrast to the east coast of the middle basin, no upwelling develops in the south basin (Tuzhilkin and Kosarev, 2005).

25 In general, at the scale of the CS, the summer gradient of salinity is stronger than that of the winter. The main influences are, on an otherwise relatively stable salinity around

\section{Lingulodinium machaerophorum expansion in the Caspian Sea}

S. A. G. Leroy et al.

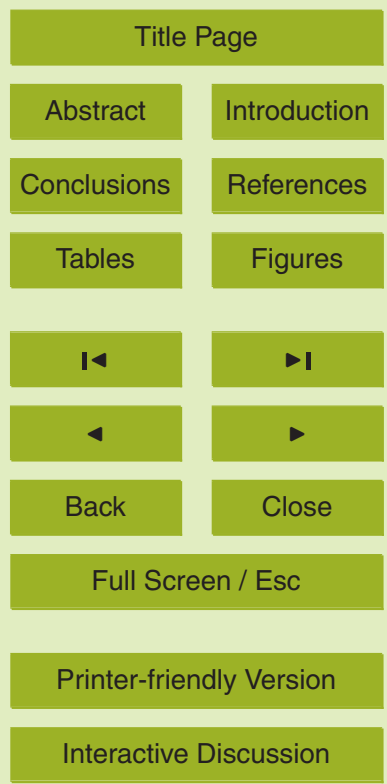

\section{7}


11-12, the freshening influence of the Volga River in the north basin (salinities less than 1), and the stronger evaporation in the southeast (salinities up to 14) (Kosarev and Yablonskaya, 1994; Dumont, 1998). Monitoring from 1956 to 2000 shows high salinities in the early 1970 s and low salinities in the early 1990 s, corresponding respectively to 5 low annual river discharge and high annual river discharge as well as the 1977 lowstand and the 1995 highstand (Fig. 2a). This water level change caused respectively a mixing of the water column and a stratification of the water column (Tuzhilkin and Kozarev, 2005). In the south basin, the summer and winter gradients show that the west is fresher (12.2) and the east more saline (13.8).

10 In the CS, summer temperature varies from $26^{\circ} \mathrm{C}$ in the $\mathrm{NW}$ to $>28^{\circ} \mathrm{C}$ in the SE. Winter temperatures are $10{ }^{\circ} \mathrm{C}$ in the centre of the basin and get cooler by 2 to 3 ${ }^{\circ} \mathrm{C}$ towards the periphery. A record of sea surface temperature in the south CS from 1982 to 2011 obtained by satellite) (Fig. 2b) shows a clear warming trend for all seasons $\left(0.10^{\circ} \mathrm{Cyr}^{-1}\right)$ by $1-2{ }^{\circ} \mathrm{C}$ and stronger for the south basin of the Caspian than the other regions (Ginzburg et al., 2005 updated by European Centre for Medium-Range Weather Forecasts, ECMWF). The warming is the strongest for the summer with an increase from a little less than $25^{\circ} \mathrm{C}$ to more than $28^{\circ} \mathrm{C}$. The extreme summer maxima show the strongest increase (Ginzburg et al., 2005). Moreover, based on hydrological data, a positive trend in the period 1900-1982 has been found but not as fast as after 1982 (Ginzburg et al., 2005). Thus the warming trend is independent of the significant sea level fluctuations that have taken place during the 20th century. A similar effect was observed in the Black Sea, Aral Sea and the Karabogaz-Gol by Ginzburg et al. (2005). These authors suggest that this warming trend could be a consequence of global warming (Fig. 2c). The sea ice season and extent in the northern basin have decreased for the period 1978 to 2002, also possibly related to global warming (Kouraev et al., 2004). For two out of the four coring locations more local information is provided in Appendix A.
BGD

9, 16663-16704, 2012

\section{Lingulodinium machaerophorum expansion in the Caspian Sea}

S. A. G. Leroy et al.

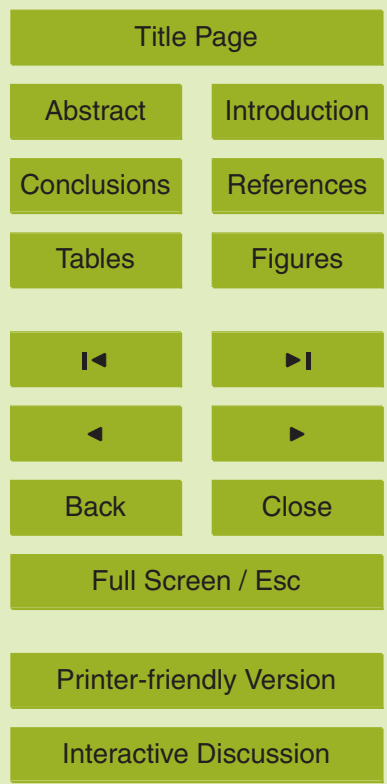




\subsection{Nutrients and phytoplankton}

Most nutrients enter the CS in the northern basin via the Volga River. The relatively low nutrient levels in the upper $100 \mathrm{~m}$ are depleted by phytoplankton activity, but the nutrient concentrations increase with depth (Kosarev and Yablonskaya, 1994). Iranian lagoons

5 and coastal regions have however been steadily polluted by anthropogenic sources (fertilizers and pesticides used in agriculture and increased nutrient load of river flows due to deforestation of woodland) since the early 1980s (Kideys et al., 2008). For two out of the four coring locations more local information is provided in Appendix A.

Changes in phytoplankton biomass are one way to assess changes in water quality. 10 Kideys et al. (2008) detected by satellite imagery an increase in chrolorophyll $a$ in the southern CS since 2001. The invasion of the comb jelly Mnemiopsis leidyi in the late 1990s caused a drop in zooplankton, which in turn favoured phytoplankton. But other factors such as overfishing, eutrophication and climatic change may also have played a role.

15 Because of the pollution and because of the introduction of M. leidyi, the status of the south coast of the CS has changed between 1994 and 2005 from oligotrophic to meso-eutrophic, and the balance between diatoms, cyanobacteria and dinoflagellates shifted in favour of the latter two (Nasrollahzadeh et al., 2008a,b).

In 2006, an anomalous algal bloom mostly due to a dinoflagellate Heterocapsa, oc20 curred in front of Anzali harbour (Bagheri et al., 2011). Other algal blooms mostly due to the toxic Cyanobacteria Nodularia spumigna occurred in August and September 2005 (20000 km $\mathrm{km}^{2}$ of the southern basin) (Soloviev, 2005) in August 2009 (off Tonekabon) and in July and early August 2010 (from Nowshahr to near Babolsar and offshore Anzali) (Nasrollahzadeh et al., 2011; Makhlough et al., 2011). It is noteworthy that $L$. polyedra contributed significantly to the 2009 bloom (Nasrollahzadeh et al., 2011).

\section{BGD}

9, 16663-16704, 2012

\section{Lingulodinium machaerophorum expansion in the Caspian Sea}

S. A. G. Leroy et al.

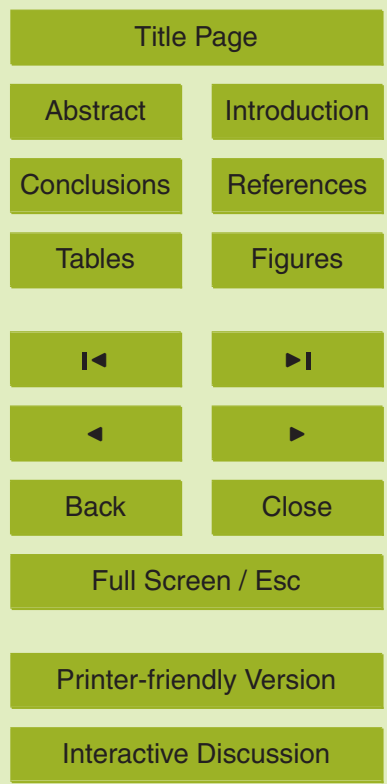




\subsection{Sediment sources and sedimentation rates}

At present, rivers flowing to the Northern Caspian Coast (the Volga, Ural, Terek and Sulak) supply approximately $90 \%$ of the riverine water influx to the CS, whereas the southwestern and southern rivers (the Sefidrud, Kura and Gorganrud) are the main 5 sources of sediments for the whole of the CS (Lahijani et al., 2008).

Studies of the CS sediment composition have so far focused on the northern basin, where the proportions of the different inputs were estimated to be $35 \%$ fluvial, $28 \%$ aeolian, $29 \%$ biogenic carbonate and $8 \%$ chemical carbonates (Khrustalyov and Artiukhin, 1992). The Iranian mountains, such as the Elburz Mountain, represent the main source of terrigenous materials in the south basin. The sediment has two main primary detrital sources, more siliclastic in the west, more carbonates in the east (Lahijani and Tavakoli, 2011). One other source is aeolian transport by numerous dust storms from Turkmenistan, where Mesozoic limestones exist in the Kopet Dag (Lahijani and Tavakoli, 2011).

The south part of the basin was subsiding at a rate of the order of $>1 \mathrm{mmyr}^{-1}$ (Einsele and Hinderer, 1997) and this is probably still the case today.

The sedimentation rates in the south basin have always been very high due to its large accommodation space, strong erosion of the surroundings and orogenesis as well as aeolian inputs. For the Cainozoic, the sedimentary deposits in the Southern Caspian basin are as much as $20-30 \mathrm{~km}$ thick, making it one of the deepest basins in the world. For the Pliocene-Quaternary time alone, $10 \mathrm{~km}$ of sediment have been deposited, providing an average accumulation rate close to $2 \mathrm{~mm} \mathrm{yr}^{-1}$ (Nadirov et al., 1997; Tagiyev et al., 1997). The sedimentation rate of the Pliocene in the south basin (the Pliocene Productive Series) is even higher up to $4 \mathrm{mmyr}^{-1}$ (Kroonenberg et al.,
BGD

9, 16663-16704, 2012

\section{Lingulodinium machaerophorum expansion in the Caspian Sea}

S. A. G. Leroy et al.

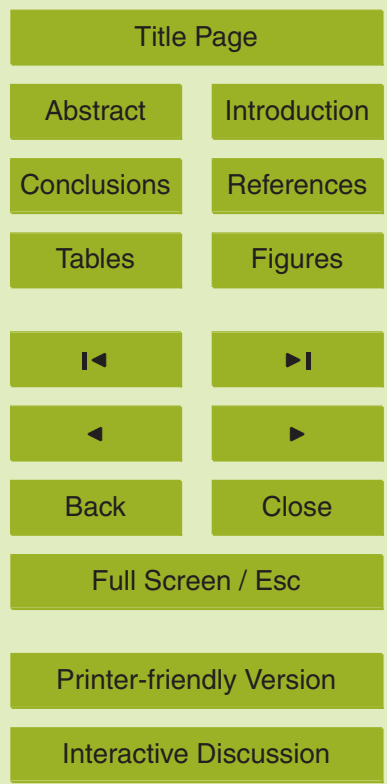




\subsection{Past dinocyst investigations in the Caspian Sea}

Some modern samples from the Caspian region were published in Marret et al. (2004), which is also the reference paper for the description of new Caspian genus, species and forms. Five surface samples were studied for their dinocyst content in the lagoon 5 of Anzali (Kazancıet al., 2004) (Fig. 1).

The dinocyst history of the area is poorly known from previous dinocyst investigations, although four records cover the last $300 \mathrm{yr}$ at least (locations in Fig. 1): in the Amirkola and Anzali Lagoons (Leroy et al., 2011), in the Gomishan lagoon, S-E corner of the CS (Kakroodi et al., 2012) and in the Karabogaz Gol (Leroy et al., 2006).

103 Materials and methods

\subsection{Collection of surface samples, coring and dating}

Modern samples were derived from a combination of core tops, grabs and hand scooping (Table A1). Sixteen samples came from marine settings, two from lakes, and nine from lagoons (locations in Fig. 1) Two Usnel boxes $(50 \mathrm{~cm}$ thick) were taken in the 15 south basin, during a French-Russian oceanographic cruise (August 1994), on board a Russian military ship, rented for the sea cruise (Table A2). Box locations were in water depths of $13 \mathrm{~m}$ for core US01 and of $315 \mathrm{~m}$ for core US02. Cores from Usnel boxes were subsampled in PVC tubes on board and therefore contain the water-sediment interface. Two Kajak heavy gravity cores with a diameter of $5 \mathrm{~cm}$, cores CS03 and CS10, were taken in 2007 from a boat rented by the Iranian National Institute for Oceanography (INIO) (Table A2).

Two of the four cores were dated by radionuclides, i.e. USO2 and CS03. ${ }^{210} \mathrm{~Pb},{ }^{226} \mathrm{Ra}$ and ${ }^{137} \mathrm{Cs}$ records were obtained. Samples of core US02 were analysed every $\mathrm{cm}$ for both ${ }^{210} \mathrm{~Pb}$ and ${ }^{137} \mathrm{Cs}$ in the top $10 \mathrm{~cm}$, then every $2 \mathrm{~cm}$ down to $16 \mathrm{~cm}$ (results in Leroy et al., 2007). A sample at $22 \mathrm{~cm}$ reaches background values. For core CS03, samples

BGD

9, 16663-16704, 2012

\section{Lingulodinium machaerophorum expansion in the Caspian Sea}

S. A. G. Leroy et al.

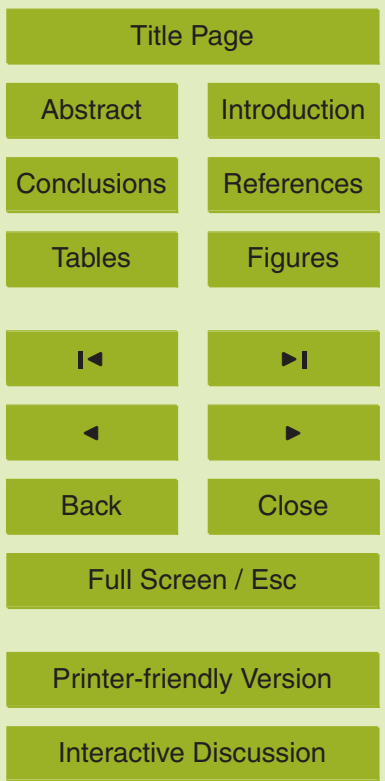


were taken at ca. $3 \mathrm{~cm}$ interval down to $60 \mathrm{~cm}$ and then at every ca. $8 \mathrm{~cm}$ interval. Dry samples were measured with a very low-background, high-efficiency well-type detector located in the underground laboratory of Modane in the French Alps (Reyss et al., 1995) where $1700 \mathrm{~m}$ of rock overburden reduces the cosmic radiation by 6 orders of 5 magnitude.

\subsection{Sedimentology}

For the sedimentary analysis of the two Usnels cores, dried samples were homogenized and representative subsamples were taken for grain size analysis by a LS 13320 Multi-Wavelength Particle Size Analyzer, ASTM standard calibrated. Organic matter and calcium carbonate contents were determined by loss-on-ignition, bulk samples were dried at $105^{\circ} \mathrm{C}$ for $24 \mathrm{~h}$, then heated to $550^{\circ} \mathrm{C}$ for $4 \mathrm{~h}$ to burn the organic matter, and organiccarbon free sample heated again to $950^{\circ} \mathrm{C}$ for $8 \mathrm{~h}$ to break the calcium carbonate. The percentages of organic matter and calcium carbonate were then calculated by the method used by Dean (1974).

15 For the two Kayak cores, samples were homogenized and representative subsamples were taken for grain size analysis. The distribution for the fraction coarser than $1 \mathrm{~mm}$ was determined using the standard wet sieving procedure. Grain-size analysis for particles less than $1 \mathrm{~mm}$ was undertaken using a "Fritsch Analysette Comfort 22" Laser Particle Sizer. Organic matter was determined by wet digestion through oxida20 tion in hydrogen peroxide on bulk samples (Schumacher, 2002). The calcium carbonate was determined by using a Bernard calcimetre.

The magnetic susceptibility was measured with a Bartington Instruments MS2 susceptibility bridge. Cores CS03 and CS10 were measured using a MS2C sensor on half cores, core US01 using MS2E1 and core US02, using MS2F sensor, both along 25 flat surface of half cores. The thermomagnetic behaviour of the bulk sediment sample from core US02, was determined on a horizontal force translation balance in air atmosphere in a magnetic field of $0.375 \mathrm{~T}$ and with a linear temperature increase.

\section{BGD}

9, 16663-16704, 2012

\section{Lingulodinium machaerophorum expansion in the Caspian Sea}

S. A. G. Leroy et al.

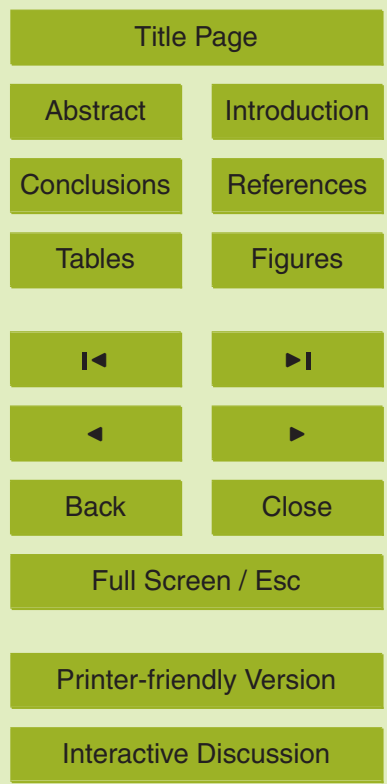




\subsection{Palynology}

Samples were taken every $5 \mathrm{~cm}$ in the four cores. Initial processing of samples (1 to $2 \mathrm{ml}$ ) involved the addition of sodium pyrophosphate to deflocculate the sediment. Samples were then treated with cold hydrochloric acid (10\% and then pure) and cold hy5 drofluoric acid $(60 \%)$, followed by a further treatment with hydrochloric acid. The residual organic fraction was then screened through $125 \mu \mathrm{m}$ and $10 \mu \mathrm{m}$ mesh sieves and mounted on slides in glycerol. Lycopodium tablets were added at the beginning of the process for concentration estimates.

The dinocysts were counted at the same time as pollen and other microfossils. The 10 sum for percentages is made of all dinocysts except Brigantedinium spp. (including all "round-brown" specimens which are cysts not identified to the species level), because of its ubiquitous character and frequent dominance of the spectra. Brigantedinium and varia are expressed as a percentage of the same sum as the other dinocysts. The percentages of the foraminifera inner organic linings found in the palynological slides 15 were displayed in the same way. A ratio pollen concentration on dinocyst concentration (P:D) has been determined according to McCarthy and Mudie (1998) in order to estimate the degree of continentality of the assemblage.

A statistical analysis available in Psimpoll (Bennett, 2007), the zonation by cluster analysis (CONISS) after square root transformation of the percentages, was applied. The zonation was calculated for the percentage diagrams.

The taxonomy of many Caspian dinocyst species has been established by Marret et al. (2004). Illustrations of Caspian dinocysts are also available in Leroy (2010) and Mudie et al. (2011). Three forms of $L m$ have been counted separately: ss, A and B. In a worldwide study, Mertens et al. (2009) indicate that $L m$ can be found in surface sed25 iment in a salinity range from at least 12.5 to 42 , and for temperature from 9 to $31^{\circ} \mathrm{C}$. The same study established that longer processes are clearly developed at higher summer salinity (Mertens et al., 2009) For the CS, the length of the processes decreases from form ss to form B.

BGD

9, 16663-16704, 2012

\section{Lingulodinium machaerophorum expansion in the Caspian Sea}

S. A. G. Leroy et al.

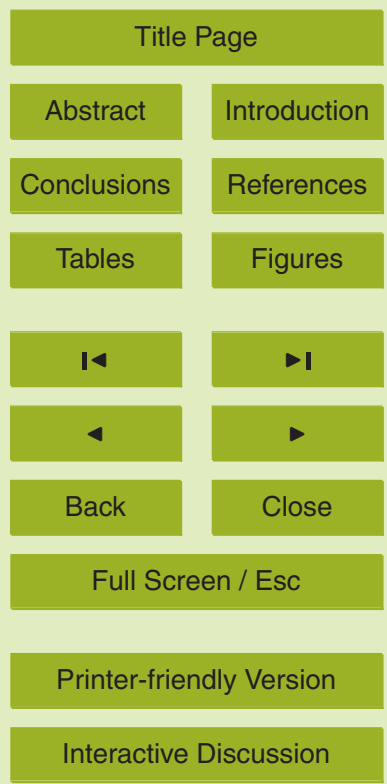




\section{Results}

\subsection{The surface samples}

The samples are organised by increasing percentage values of $L m$ B from the top to the bottom of Fig. 5, except the bottom two samples which have high values of forms 5 ss and $A$.

At the top of the diagram, the assemblages of the two lake samples (Almagol and Alagol) are composed only of Brigantedinium. At the bottom of the diagram, the dinocysts are dominated by $L m$ B with increasing values of $L m$ ss and often the presence of $S$. belerius (saline lagoons of BTork 1 and 2, and TR1). The bottom-most two samples are derived from hypersaline settings: the Aral Sea (AS17-5) and the Karabogaz Gol (KBG8-01) explaining respectively the abundance of $L m$ ss and the high peak of $L m A$.

In the middle sample group, the spectra are dominated by I. caspienense and Caspidinium rugosum rugosum, with occasionally at the top end of the diagram the development of Pentapharsodinium dalei and S. cruciformis, respectively in north of the middle Caspian basin (cores US24 and US26) or more freshwater lagoons (Anzali).

\subsection{Core sediment and dating}

The sediment of core US01, off the coast of Turkmenistan, is silty with up to $20 \%$ clays. It has the highest amount of sand of the four cores, reaching 10-20\% (Fig. 4).

20 The core bottom has $4 \%$ organic matter, but this rapidly decreases upwards to $1 \%$. The carbonate content is stable around $20 \%$. The magnetic susceptibility is very low and increases upwards. Foraminifera tests are abundant (Appendix B).

The sediment of core US02, from the middle of the south basin, is clayey and silty with some sand from $8.5 \%$ at the base to $2 \%$ at the top. The organic matter progressively increases from 2 to $4 \%$. This sequence has the highest content in carbonates of the four cores, reaching $30-40 \%$. It is likely that some of the carbonate is derived

\section{Lingulodinium machaerophorum expansion in the Caspian Sea}

S. A. G. Leroy et al.

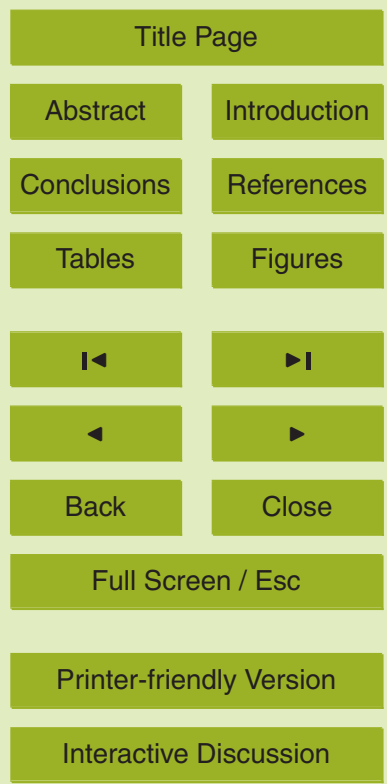


from benthic ostracod valves as they are known in the top $\mathrm{cm}$ of this core (Boomer et al., 2005). The magnetic susceptibility is low. The Curie temperature for sample at $6 \mathrm{~cm}$ depth was $580^{\circ} \mathrm{C}$; the mineral carrying the magnetic susceptibility is magnetite $\left(\mathrm{Fe}_{3} \mathrm{O}_{4}\right)$.

5 The sediment of core CSO3, offshore from Anzali, is comprised of gray silts and clays with darker layers. The sediment is occasionally bioturbated by a network of animal tubes. The mean amounts of organic matter and carbonates are stable with respectively values of 3 and $17 \%$. The magnetic susceptibility is low.

The sediment of core CS10, taken offshore from Babolsar, consists of clayey silts, 10 sometimes with very fine sand, poorly sorted, getting darker with depth, ranging from dark grey to black with a reduced-sediment odour. Sediments are laminated through much of the sequence. Some part of the sequence appears burrowed (particularly the lower portion). The sequence has $3 \%$ of organic matter and $20 \%$ of carbonates as well as the highest magnetic susceptibility of the four cores.

15 The radionuclide results of core US02 have been published in Leroy et al. (2007). In brief the sedimentation rate obtained is $2.0 \mathrm{~mm} \mathrm{yr}^{-1}$ for the top $22 \mathrm{~cm}$ of sediment. The base of the core is therefore estimated to be at AD 1709.

For core CS03, the record of artificial fallout radionuclides ${ }^{241} \mathrm{Am}$ and ${ }^{137} \mathrm{Cs}$ (Fig. 5) detected in the upper $104 \mathrm{~cm}$. of sediment display a maximum at $83 \mathrm{~cm}$ depth that is assigned to the period of maximum weapons fallout (Appleby, 2000) The corresponding averaged sedimentation rate is thus of $19 \mathrm{~mm} \mathrm{yr}^{-1}$. The radiometric ${ }^{210} \mathrm{Pbexc}$ profile (Fig. 5) does not display the regular exponential decrease with depth in the core as expected for a constant sedimentation rate. For the upper $63 \mathrm{~cm}$, the profile exhibits a roughly linear decreasing activity corresponding to a sedimentation rate of $20 \mathrm{~mm} \mathrm{yr}^{-1}$ 25 in good agreement with the artificial radionuclide results. Deeper in the core, the data are more scattered and would correspond to a higher sedimentation rate. Assuming that the sedimentation rate of the deeper part of the core is higher than $20 \mathrm{~mm} \mathrm{yr}^{-1}$, the age of the base of the core is estimated between AD1963 and AD1930. The use of other models (CIC, CRS, Appleby 2000, and SIT, Carroll and Lerche 2003) was not

\section{BGD}

9, 16663-16704, 2012

\section{Lingulodinium machaerophorum expansion in the Caspian Sea}

S. A. G. Leroy et al.

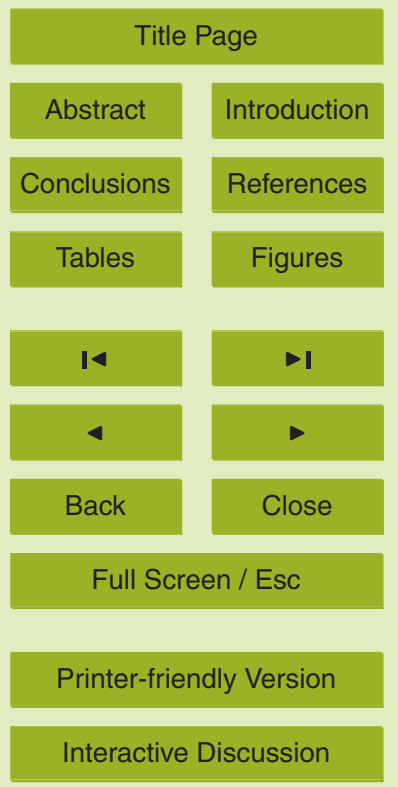


attempted because of the large discontinuities in the sampling depths. The sedimentation rate that was obtained, $20 \mathrm{mmyr}^{-1}$ is therefore exceptionally high and 10 times higher than that of core US02.

No dating is available for cores US01 and CS10. It is however likely that the sedi5 mentation in front of the Babolsar River, for core CS10, will be similar or slightly lower than that of core CS03 because the Babolsar river (in front of the CS10 coring location) sediment discharge is minute when compared to that of the Sefidrud (a powerful river, but east of core CS03): 0.411 Mton yr $^{-1}$ versus 26000 Mton yr $^{-1}$ (Lahijani et al., 2008).

\subsection{Dinocysts in the four cores}

10 In general the same range of taxa is found in the four cores (Fig. 6), with the usual dominance of $I$. caspienense and the abundance of $L m$ under two forms: B and ss (Marret et al., 2004). P. psilata has only rare occurrences.

\subsubsection{Core US1, the shallow core off Turkmenistan}

This sequence is largely dominated by only two taxa: I. caspienense whose percent15 ages decrease slightly from 60 to $40 \%$, and $L m$ B whose percentages increase. $L m$ ss and $S$. belerius have continuous curves. The $P: D$ ratio is very low (if compared to modern samples, Fig. 3) indicating that more dinocysts than pollen are preserved in the sediment and therefore that the continental influence is low despite the proximity of the continent and that the dinocysts have found optimal conditions to grow.

20 Foraminifera linings have been found in significant numbers throughout the core and form a continuous curve.

\subsubsection{Core US2, the last $\mathbf{3 0 0} \mathrm{yr}$ in the middle of the south basin}

Zone US02-d1 has relatively high $S$. cruciformis values and a significant percentage of $C$. rugosum, not met in the surface samples. Zone US02-d2 has slightly less $S$. cruciformis, much less $C$. rugosum and slightly more $L m$ B.

16676

\section{BGD}

9, 16663-16704, 2012

\section{Lingulodinium machaerophorum expansion in the Caspian Sea}

S. A. G. Leroy et al.

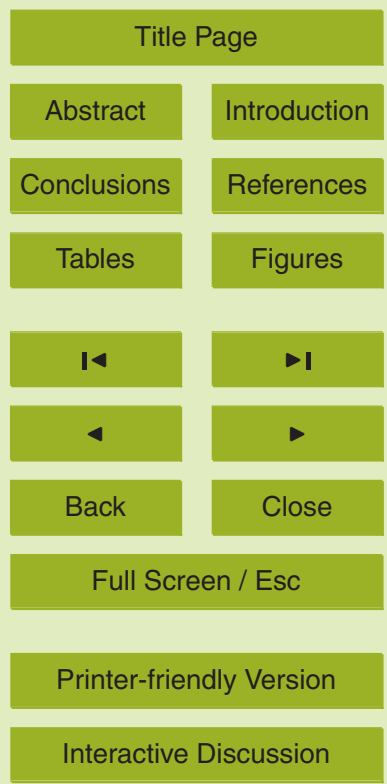


The concentration is the lowest of the four cores due to the distance to the shores. The relatively low $P$ : $D$ displays an increasing overall trend. This diagram shows a mild trend to have opposite fluctuations of $P$. dalei cysts (highest values of the 4 cores) and $L m B$. This core overall shows assemblages that indicate the lowest salinities of the

5 four cores. This is due to its location in a more open sea. No foraminifera linings have been found in this sequence as the water depth is too great for the survival of these benthic organisms in the CS (Boomer et al., 2005).

\subsubsection{Core CS03, the 20th century off Anzali}

In zone CS03-d1 I. caspienense has maximal values, $P$. dalei cysts are well represented and the percentages of Brigantedinium are relatively high. The concentration increases slowly and the P:D decreases upwards. In zone CS03-d2, $L m$ B values are nearly twice as high as before. $P$. dalei cysts become rare. The concentration is clearly higher than in zone 1 , while $P: D$ is stable. This core shows a compelling opposition between $P$. dalei cysts and $L m$ B.

15 The coring location $15 \mathrm{~km}$ offshore, does not seem to be influenced by the freshwater outflow from the Anzali lagoon.

\subsubsection{Core CS10, with massive algal biomass increase off Babolsar}

In zone CS10-d1, the values of $I$. caspienense are the highest of the four cores. The $P: D$ is extremely high: showing a clear terrestrial influence similar to that in surface samples, e.g. in lakes (such as Alagol) and lagoons (Anzali and Bandar-e-Torkman).

In zone CS10-d2, after a sudden change, high percentages of $L m$ B (80\%) occur. These are also the highest values ever recorded in the CS. This occurs in parallel to a huge increase in the dinoflagellate cyst biomass.

The limit between zones CS03-d1 and $\mathrm{d} 2$ corresponds well to that between zones CS10-d1 and d2, with the same increase in $L m$ B and ss percentages and in total biomass and the same decrease in Brigantedinium and in the P/D ratio. This change at

BGD

9, 16663-16704, 2012

\section{Lingulodinium machaerophorum expansion in the Caspian Sea}

S. A. G. Leroy et al.

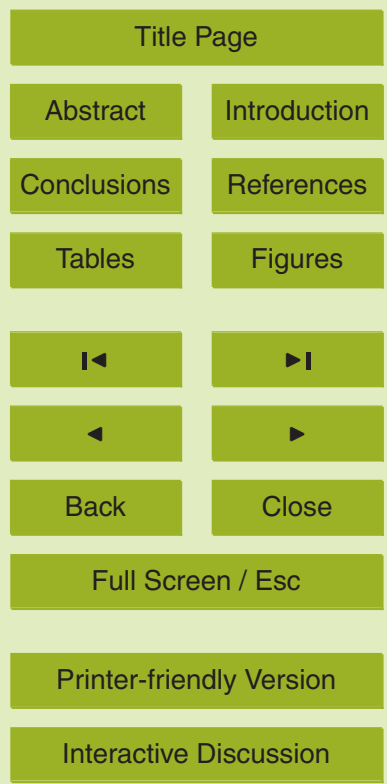


$75 \mathrm{~cm}$ is well dated in core CS03 as it is just a few $\mathrm{cm}$ above the ${ }^{237} \mathrm{Cs}$ peak of AD1963 at $83 \mathrm{~cm}$, bringing the age of the limit at AD1967.

BGD

9, 16663-16704, 2012

\section{Discussion}

\subsection{Dinocyst distributions}

5 The spectra from the surface sediment and the four cores are largely dominated by $I$. caspienense and $L m$. The near absence of $P$. psilata and the low values of $S$. cruciformis (for the latter except the central core and some surface samples in the Lagoon of Anzali) are a characteristic of these four recent records and of the surface samples. $P$. psilata is mostly found in Khvalynian sediment (Leroy, personal communication, 2012) and in lagoons and river deltas such as the Demchik area of the Lower Volga River (K. Richards, personal communication, 2012). This is easily explained both in terms of the higher salinity of the Neocaspian Sea and in terms of survival in lagoons where the salinity is variable and where the lagoons maintain at most times at least small areas of lower salinity if fed by rivers. The higher values of S. cruciformis in zone US02-d1 may reflect the much higher water levels of the LIA, which also have less saline waters as also seen in the lagoon of Anzali (Leroy et al., 2011).

The two southern cores have the highest percentages of Brigantedinium. This is explained by the proximity of a densely inhabited coastal area producing a lot of nutrients discharged into the sea.

20 The cosmopolitan species $P$. dalei cyst is clearly more abundant in the northern surface samples (samples US24 and 26), which are characterised by larger amplitudes of sea surface temperatures and the proximity of sea ice in winter (Marret et al., 2004).

On the one hand, based on the locations of the cores and the surface samples, it is possible to show that the three $L m$ forms show an increasing salinity gradient from $B$, 25 to ss and finally to $A$. On the other hand, $L m$ percentages (all forms included) display an increase across the CS to the southeast, i.e. towards regions that are warmer and

\section{Lingulodinium machaerophorum expansion in the Caspian Sea}

S. A. G. Leroy et al.

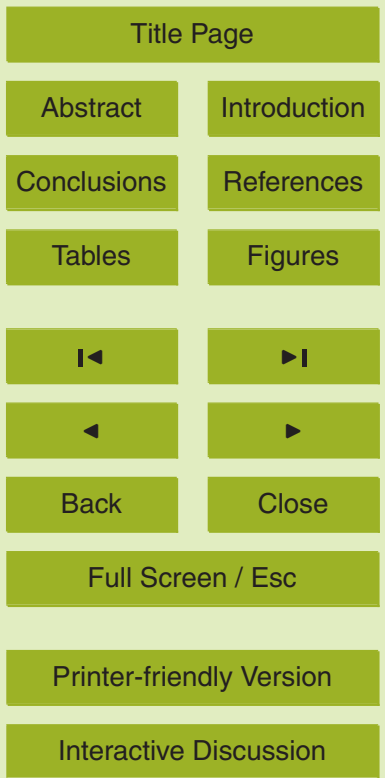


more saline. So the morphology of the cysts responds to the salinity but its biomass to temperature.

BGD

\subsection{Exceptional sedimentation rate}

The sedimentation rate of core US02, in the centre of the south basin, obtained by 5 the radionuclide method is $2 \mathrm{mmyr}^{-1}$. This is 10 times higher than that obtained by radiocarbon on core CP14 taken close by (Leroy et al., 2007). This difference could be caused not only by an expected lack of compaction of the top tens of $\mathrm{cm}$ of sediment in core US02 but also by a very recent (the last few centuries) increase of the sedimentation influx (Leroy et al., 2007). This radiocarbon-based value falls within the sedimen10 tation rates of other cores from the deep basins i.e. between 0.02 and $0.54 \mathrm{~mm} \mathrm{yr}^{-1}$ (Amini et al., 2012).

The sedimentation rate in a short core (HCGA05, $170 \mathrm{~cm}$ long) from the Anzali Lagoon, is of $5 \mathrm{mmyr}^{-1}$, that of core HCGL02 (95 cm long) in the lagoon of Amirkola is $2.5 \mathrm{mmyr}^{-1}$ (Leroy et al., 2011), and that in cores from the Gorgan Bay is between 151.4 and $2.45 \mathrm{~mm} \mathrm{yr}^{-1}$ (Karbassi and Amirnezhad, 2004). These values are higher than those from the core from the centre of the south basin. These lagoonal settings are expected to have higher sedimentation rates than those of the open sea.

On the whole the values of the short cores are in the order of the sedimentation for the Cainozoic (Nadirov et al., 1997; Tagiyev et al., 1997).

20 However $20 \mathrm{mmyr}^{-1}$ obtained on the coastal core CSO3 is truly exceptional (Amini et al., 2012). This value is even higher than that of the Pliocene Productive Series (Kroonenberg et al., 2005). This is explained by the core location on the slope of the continental shelf. The time resolution of the palynological samples therefore reaches one sample every $2.5 \mathrm{yr}$.
9, 16663-16704, 2012

\section{Lingulodinium machaerophorum expansion in the Caspian Sea}

S. A. G. Leroy et al.

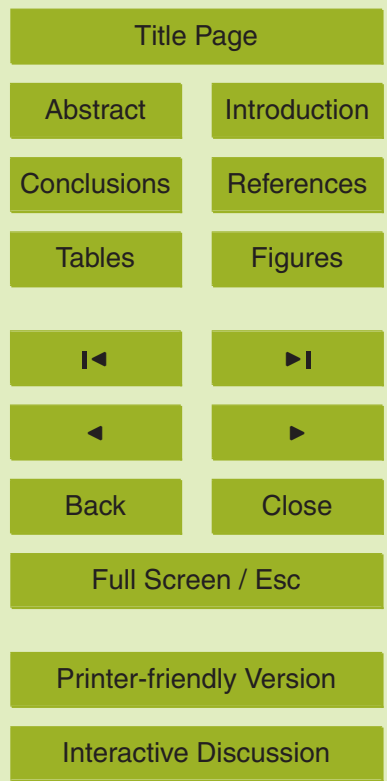




\subsection{Shifts in the L. machaerophorum percentages}

This section focuses on what causes the increase in $L m$ visible in the four cores, more so for the two southern ones (Figs. 6, 7). Moreover these increases of $L m$ are often to the detriment of $P$. dalei cysts when present in the cores. The recent changes are then

5 set in the context of the changes in the last few millennia.

\subsubsection{In the last decades}

$L$. polyedra, the motile form of $L m$ usually occurs in the water column during late summer, which suggests that a minimum temperature is needed for its development. $L$. polyedra can bloom in nutrient rich and nutrient depleted waters: thus its distribution does not have to be restricted to areas with high nutrient concentrations in surface waters (Lewis and Hallett, 1997). Dinoflagellate biomass that shows a steep increase as part of anomalous algal blooms that occurred in the last few years in the CS are probably seen in the strong algal biomass increase across core CS10, especially since 1967. The causes for this are multiple, and are often attributed to nutrient washed into 15 the sea by the rivers; however they are also often linked to higher temperature and low wind conditions and therefore stratified waters (Soloviev, 2005; Nasrollahzadeh et al., 2011). A remote sensing analysis for the 2005 large-scale bloom indicated that an increase of $4{ }^{\circ} \mathrm{C}$ was observed in the bloom itself in comparison to surrounding waters. Low wind conditions and water stratification were also observed. In brief this would tend to indicate that $L$. polyedra responds primarily to high temperatures, with salinity, and nutrients as secondary factors.

In the 20th century, the water level has fluctuated by $\pm 3 \mathrm{~m}$ a couple of times (Fig. 2a), but this seems to have been hardly registered in the fossil record (Fig. 6). More decisively, the sharp sea level rise between 1977 and 1995 has led to a salinity decrease. 25 However $L m$ percentages have strongly increased, more in line with the gradual increase of sea surface and air temperatures throughout this period (Fig. 2b-d)

BGD

9, 16663-16704, 2012

\section{Lingulodinium machaerophorum expansion in the Caspian Sea}

S. A. G. Leroy et al.

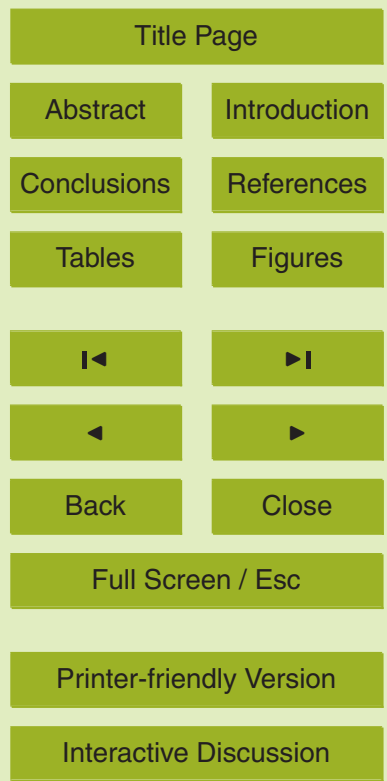




\subsubsection{In the Late Holocene}

Successive dinocyst phases are characterised by the dominance of various dinocysts in the later part of the Late Pleistocene-Holocene history of the CS: (1) the most recent is a $L m$ phase in the last few decades, (2) the next one is dominated by $I$. caspienense

5 until ca. 3.9 cal. ka ago, and (3) the oldest one, covering the early Holocene and Late Pleistocene, is dominated by $S$. cruciformis and $P$. psilata. This succession was already suspected in core CP14 (Leroy et al., 2007), but it is only with the additional cores US01, US02, CS03 and CS10 that the most recent phase became clearly visible.

The examination of thirteen records reveals the following history in the development 10 of $L m$ (Figs. 1, 7). It is quasi absent from a $10 \mathrm{~m}$ long core in the centre of the south basin, core GS05, whose top reaches ca. 4000 yr ago (Pierret et al., 2012; Leroy, personal communication, 2012) and only present in the top $\mathrm{cm}$ of a $10 \mathrm{~m}$ long core in the centre of the middle basin, core GS18, from ca. $2900 \mathrm{yr}$ ago onwards (Boomer et al., 2005; Leroy, personal communication, 2012). In the Holocene lagoonal core TM

15 in Gomishan, SE of the south basin, $L m$ starts to develop only from ca. $3200 \mathrm{yr}$ ago (Kakroodi et al., 2012). In the marine cores CP14, 18 and 21 covering most of the second half of the Holocene (Leroy et al., 2007), a steady increase is observed. More especially in core CP14, Lm starts to develop ca. $2500 \mathrm{yr}$ ago (Leroy et al., 2007). The other much shorter records, KBG08, HCGL02 and HCGA05, show the abundance of this dinocyst in the last few centuries (Leroy et al., 2006, 2011). In core HCGA05, Anzali Lagoon (Leroy et al., 2011), Lm fluctuates in anti-phase with S. cruciformis; this was interpreted as a salinity signal. The highest percentages of $L m B, 80 \%$, and $L m A$, $80 \%$, are respectively found in core CS03 (Iranian coast) and in the Karabogaz-Gol.

Contrary to the CS, in the Black Sea, $L m$ is already present at the beginning of the

Holocene. In the SW of the Black Sea, Lm occurs in cores M02-45 and MAR05-13 respectively over the last 9500 uncal. ${ }^{14} \mathrm{C}$ years and 11000 uncal. ${ }^{14} \mathrm{C}$ years (Marret et al., 2009; Bradley et al. 2012) (note that the Black Sea radiocarbon dates are often uncalibrated and uncorrected for the reservoir effect due to major uncertainties). From

BGD

9, 16663-16704, 2012

\section{Lingulodinium machaerophorum expansion in the Caspian Sea}

S. A. G. Leroy et al.

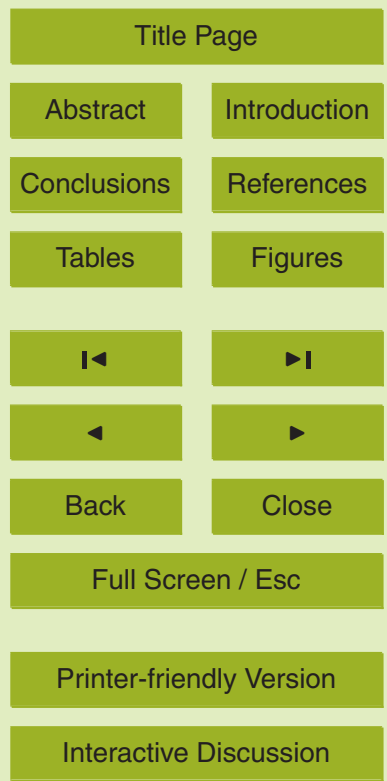


6 uncal. ${ }^{14} \mathrm{C}$ ka, it is even largely dominant. It peaks from 6 to 5 uncal. ${ }^{14} \mathrm{C}$ ka, which is considered the warmest period in the climate of the Black Sea region. The topmost part of the core estimated to be close to the present shows at least $80 \%$ of $L \mathrm{~m} \mathrm{ss}$. Marret et al. (2009) suggested that these high values were due to anomalous blooms 5 of this species.

In a Marmara Sea sedimentary sequence, Verleye et al. (2009) found an opposition similar to that of the present study between $L m$ and $P$. dalei cysts interpreted here as less river input versus higher terrigenous input. In the Sea of Barents, the abundance of cysts of $P$. dalei increases according to Voronina et al. (2001) near high productivity 10 waters. An investigation of dinocysts in a core from the Marmara Sea covering the Late Pleistocene and Holocene considers $L m$ as a thermophilous taxon (Londeix et al., 2009).

In brief in the CS, contrary to the Black Sea, it appears that the Lm development started slowly only ca. $3200 \mathrm{yr}$ ago and has strongly accelerated in the last decades.

15 The causes of this appearance and development of $L m$, are not sea levels that have fluctuated widely during that time period. During the LIA, the water level was $6 \mathrm{~m}$ higher than at present (archaeological and documentary evidences in Brückner, 1890; palaeoenvironments in Leroy et al., 2011). During the early Middle Ages, the water levels were lower by $2-4 \mathrm{~m}$ as attested by the numerous walls built by the Sasanian 20 Empire (archaeological and documentary evidences in Brückner, 1890; Omrani et al., 2007). A high stand similar to the LIA has been recorded between 2600 and 2300 cal. yr BP (sediment in Kroonenberg et al., 2007; Kakroodi et al., 2012). These important changes have so far not been recorded in the $L m$ curve.

Causes for the increase in $L m$ percentages and biomass should be sought more in 25 a regional signal such as a possible long-term recovery from glacial meltwater inflow (Leroy et al., 2007) or at a global level.

\section{BGD}

9, 16663-16704, 2012

\section{Lingulodinium machaerophorum expansion in the Caspian Sea}

S. A. G. Leroy et al.

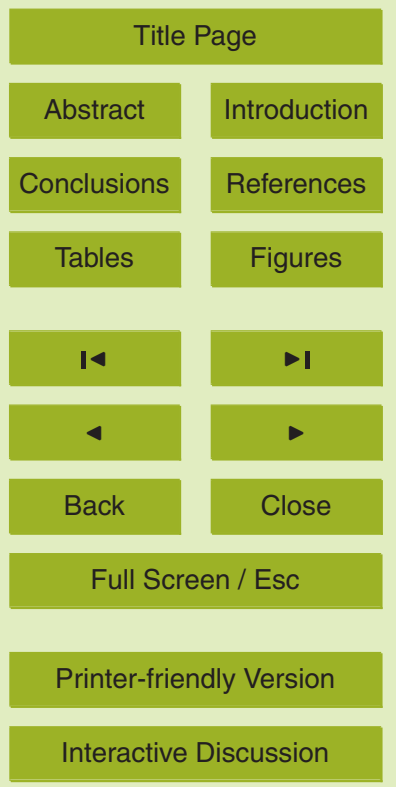




\subsection{L. machaerophorum increase and sea surface trends}

Changes in phytoplankton abundance may be driven by several factors that may confound the climatic signal (Adrian et al., 2009). In the present situation, it is however possible to eliminate two important factors that may have explained the changes in

$5 L m$ : sea level changes, hence salinity, and also eutrophication. Indeed (1) sea level changes have taken place in the last millennia and even centuries but did not affect the percentages of $L m$; and (2) because the shift to increased values of $L m$ is older than anthropogenic eutrophication and because here $L m$ is inversely correlated to $P$. dalei, eutrophication may be secondary only in explaining the CS trend.

The temperature trend across the later part of the Holocene, due to a long-term recovery from the end of the meltwater inflow into the CS, is the initial forcing factor. The recent global warming trend detected in the CS 20th century instrumental data (air and sea surface), and confirmed for the first decade of the 21 st century (Fig. $2 b-d$ ), has fuelled the further increase of $L m$.

15 In brief, it has been shown that the increase of $L m$ is due first to natural global and/or regional climatic forcing working at the millennial timescale, such as a long-term recovery from meltwater inflow, and secondly it was amplified by a recent warming of the surface waters likely related to a recent anthropogenic-induced global forcing in the last decades. The temperature increase is the primary forcing factor, and salinity increase is just a corollary, reinforced by the closed basin setting.

\section{Conclusions}

This study is the first to provide an analysis of modern and very recent dinocyst assemblages for the Caspian Sea, with more details for the south basin in some cores with exceptional sedimentation rates.

25 This investigation of surface samples has provided a baseline for the present state of the CS and surroundings, with the dinocysts reflecting water parameters. This may

\section{BGD}

9, 16663-16704, 2012

\section{Lingulodinium machaerophorum expansion in the Caspian Sea}

S. A. G. Leroy et al.

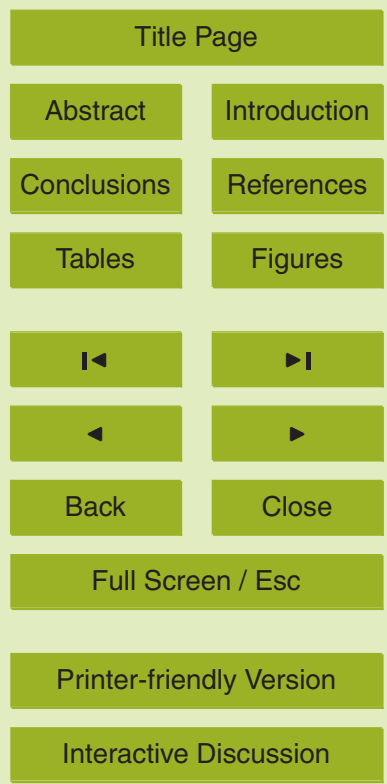


serve as a reference when comparing it with past states and future ones. More specifically for the present, the following was observed: more $P$. dalei cysts in the north at proximity to winter sea ice and with larger seasonal contrasts, more S. cruciformis in freshwater lagoons or in the oligohaline north, and more $L m$ in the warmer south and 5 in higher salinity settings.

New analyses of four short cores in the CS have shown a recent expansion of the dinoflagellate cyst $L m$. This species of dinoflagellate could be taken as an indicator of sea surface temperature. When these results are placed in the context of thirteen sequences in the CS, a robust signal is obtained: the dinocyst trend is the end result

of a natural increase that has started two or three millennia ago in the Holocene. The overall trend has recently been amplified by global warming as shown by instrumental data. This warming has significantly changed the dinocyst assemblage in the CS.

The dinocyst assemblages and the sea surface temperatures indicate that the CS has moved into the Anthropocene (Crutzen, 2002) as many other lakes (Adrian et al., 2009). The CS is a fragile ecosystem exploited by multiple users who each wish to sustain their economical development and who will have to change in order to adapt to the present changes.

\section{Appendix A}

\section{Modern oceanographic parameters for Anzali and Babolsar}

20 Offshore from Anzali (one of the four main studied locations, S-SW Caspian coast of Iran, Fig. 1) across the four seasons of the year 2006, the temperature and salinity profiles at a station with $50 \mathrm{~m}$ water depth indicate a constant temperature down to $30 \mathrm{~m}$ followed by a thermocline $\left(26\right.$ to $\left.9^{\circ} \mathrm{C}\right)$. The salinity $(9.32$ and 12.25$)$ is also constant, with just a drop in surface waters in February (Bagheri et al., 2011).

25 The temperature structure offshore from Babolsar (close to another one of the four main studied locations, S-SE Caspian coast of Iran, Fig. 1) is characterized by a strong

\section{BGD}

9, 16663-16704, 2012

\section{Lingulodinium machaerophorum expansion in the Caspian Sea}

S. A. G. Leroy et al.

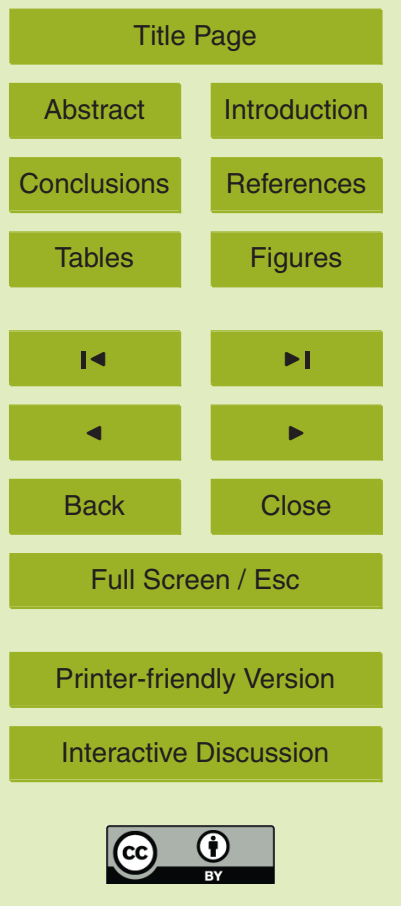


seasonal thermocline, located between 20 and $50 \mathrm{~m}$ depth with a $15^{\circ} \mathrm{C}$ temperature difference across it in summer. In autumn, the thermocline gradually weakens and, at the end of winter, it disappears before its re-formation in the early spring. The salinity is 12 with a slight decrease to 11 in enhanced river flow to the sea (Zaker et al., 2007, 5 2011).

Temperature and salinity measurements along the Iranian coast show similar temperatures but with slightly wider seasonal amplitude in the west (Table A1). The salinity increases eastwards because of the inflow of freshwater in the west via Anzali lagoon and the Sefidrud River.

10 No sewage control exists in Babolsar: industrial, domestic and agricultural wastes go to the sea via the river. Moreover, in both the flat coastal plains of Anzali-Rasht and Babolsar, a significant source of nutrients is derived from the fertilizers used in the rice fields

\section{Appendix B}

15 The analysis of foraminifera tests in core US01

\section{B1 Materials and methods}

Due to the continuous presence of foraminifera linings in palynological slides, core US01 was selected for foraminifera test analyses. Seven samples were taken at approximately $5 \mathrm{~cm}$ intervals. The samples were dried at $50^{\circ} \mathrm{C}$ in an oven and weighed. Subsequently the samples were treated with a $4 \%$ solution of $\mathrm{H}_{2} \mathrm{O}_{2}$ for $15 \mathrm{~h}$ and were wet sieved through mesh sizes of $53,63,125,250 \mu \mathrm{m}$ and then were dried again. Afterwards, all foraminifera were picked and identified from 53, 63, 125 and $250 \mu \mathrm{m}$ fractions under a binocular microscope and finally percentages were calculated for each species. In the case of samples rich in foraminifera, the samples were split into 1/8 prior
BGD

9, 16663-16704, 2012

\section{Lingulodinium machaerophorum expansion in the Caspian Sea}

S. A. G. Leroy et al.

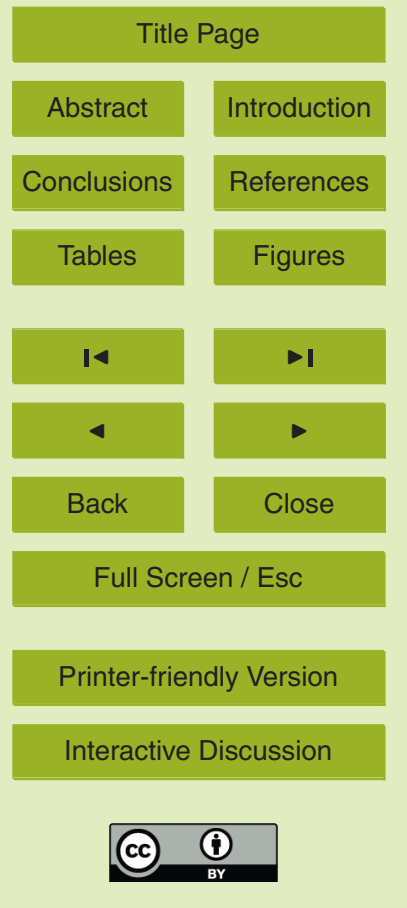


The taxonomic classification followed the suprageneric taxonomy of Loeblich and Tappan (1987), with some information from Birshtein et al. (1968).

\section{B2 Results}

The sediment contains five different euryhaline benthic foraminifera taxa: Ammonia

beccarii (47-87\%), Elphidium littorale (also known as Elphidium littorale caspicum, Retroelphidium littorale, Retroelphidium caspicum, Elphidium caspicum caspicum and E. gunteri) (10-52\%), Elphidium shochinae (0.9-0.83\%), Elphidiella brotzkajae (0.6$4.87 \%$ ) and Cornuspira sp.(0.11\%) (Fig. D1). Ammonia beccarii is the most abundant taxon in this core and Elphidium shochinae and Cornuspira sp. are the rarest.

The comparison of foraminifera abundance between the four fractions shows a maximum abundance in the 63-125 and 125-250 $\mu \mathrm{m}$ fractions. The maximal abundance of foraminifera is at $24 \mathrm{~cm}$ depth, with assemblages displaying a dominance by Ammonia beccarii. The lowest foraminifera concentration is recorded at $7 \mathrm{~cm}$ depth (Fig. D1). In the entire core, $A$. beccarii maximum abundance is at $14 \mathrm{~cm}$ depth and minimum 5 abundance at the $34 \mathrm{~cm}$ of core, but the abundance of $E$. littorale is reversed at these depths.

The core US01 is characterized by silty sediments with sand and clay with low organic matter except below $27 \mathrm{~cm}$ depth where it reaches $5 \%$. A. beccarii dominates this core and is indicative of a shallow-marine environment with sandy bottom (Sgarrella and Moncharmont Zei, 1993). However below $20 \mathrm{~cm}$ depth, Elphidium littorale is more abundant and this could be paralleled to the higher organic matter values.

\section{BGD}

9, 16663-16704, 2012

\section{Lingulodinium machaerophorum expansion in the Caspian Sea}

S. A. G. Leroy et al.

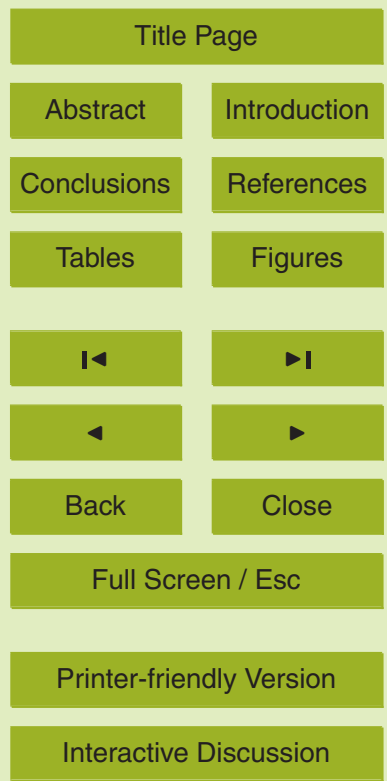


Acknowledgements. Our gratitude goes to F. Gasse, the leader of the project "Understanding the Caspian Sea erratic fluctuations", European Contract INCO-Copernicus no. IC15-CT960112, to F. Guichard and P. Tucholka for collection of Usnel box cores, to P. J. Giannesini and E. Moreno, past and present curators of cores from the Caspian Sea (Laboratoire de Géologie, 5 Museum d'Histoire Naturelle de Paris, France). We are grateful to M. Naderi (INIO) who helped in the field. The Golestan samples were kindly provided by A. A. Kakroodi. All the palynological samples were treated at Brunel University by $\mathrm{C}$. Miller, who also made the magnetic susceptibility measurements of the two Kajak cores. This article is a contribution to the European project Marie Curie, CLIMSEAS-PIRSES-GA-2009-247512: "Climate Change and Inland

10 Seas: Phenomena, Feedback and Uncertainties. The Physical Science Basis". S. Kershaw and L. López-Merino (Brunel University) have provided critical feedback on earlier versions of the manuscript.

\section{References}

Adrian, R., O'Reilly, C. M., Zagarese, H., Baines, S. B., Hessen, D. O., Keller, W., Livingstone, D. M., Sommaruga, R., Straile, D., Van Donk, E., Weyhenmeyer G. A., and Winder, M.: Lakes as sentinels of climate change, Limnol. Oceanogr., 54, 2283-2297, 2009.

Amini A., Mousavi Harami, R., Lahijani, H., and Mahboubi, A.: Holocene sedimentation rate in Gorgan Bay and adjacent coasts in southeast of Caspian Sea, J. Basic Appl. Sci. Res., 2, 289-297, 2012.

Appleby, P. G.: Radiometric dating of sediment records in European mountain lakes, J. Limnol., $59,1-14,2000$.

Arpe, K. and Leroy, SAG: The Caspian Sea Level forced by the atmospheric circulation as observed and modeled, Quatern. Int., 173-174, 144-152, 2007.

Arpe, K., Bengtsson, L., Golitsyn, G. S., Mokhov, I. I., Semenov, V. A., and Sporyshev, P. V.: Connection between Caspian Sea level variability and ENSO, Geophys. Res. Lett., 27, 26932696, 2000.

Arpe, K., Leroy, S. A. G., Lahijani, H., and Khan, V.: Impact of the European Russia drought in 2010 on the Caspian Sea level, Hydrol. Earth Syst. Sci., 16, 19-27, doi:10.5194/hess-1619-2012, 2012.

BGD

9, 16663-16704, 2012

\section{Lingulodinium machaerophorum expansion in the Caspian Sea}

S. A. G. Leroy et al.

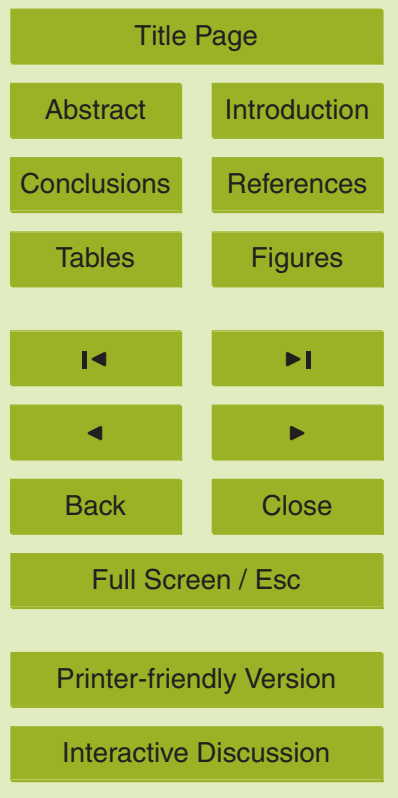


Bagheri, S., Mansor, M., Makaremi, M., Sabkara, J., Wan Maznah, W. O., Mirzajani, A., Khodaparast, S. H., Negarestan, H., Ghandi, A., and Khalilpour, A.: Fluctuations of phytoplankton community in the coastal waters of Caspian Sea in 2006, Am. J. Appl. Sci., 8, 1328-1336, 2011.

5 Bennett, K.: Psimpoll and pscomb programs for plotting and analysis, Version psimpoll 4.27, available at: http://chrono.qub.ac.uk/psimpoll/psimpoll.html (last access: 26 July 2012), 2007.

Birshtein, Y. A., Vinogradov, L. G., Kondakov, N. N., Astakhova, M. S., and Romanova, N. N. (Eds.): Atlas of Invertebrates of the Caspian Sea, Pishchevaya Promyshlennost, Moscow, 101968 (in Russian).

Boomer, I., Hoorne, D., and Slipper, I. J.: The use of ostracods in palaeoenvironmental studies, or what can you do with an ostracod shell?, Paleontol. Soc. Papers, 9, 153-179, 2003.

Boomer, I., von Grafenstein, U., Guichard, F., and Bieda, S.: Modern and Holocene sublittoral ostracod assemblages (Crustacea) from the Caspian Sea: a unique brackish, deep-water environment, Palaeogeogr. Palaeocl., 225, 173-186, 2005.

Bradley, L., Marret, F., Mudie, P., Aksu, A., and Hiscott, R.: Constraining Holocene sea-surface conditions in the southwestern Black Sea using dinoflagellate cysts, J. Quaternary Sci., 27, 835-843, doi:10.1002/jqs.2580, 2012.

Brückner, E.: Klima-Schwankungen seit 1700 nebst Bemerkungen über die Klimaschwankungen der Diluvialzeit. Geographische Abhandlungen herausgegeben von Prof. Dr Albrecht Penck, E. Hölzel, Vienna and Olmütz IV (2), 153-484, 1890.

Carroll, J. and Lerche, I.: Sedimentary Processes: Quantification Using Radionuclides, Elsevier, Oxford, 2003.

Cazenave, A., Bonnefond, K., Dominh, K., and Schaeffer, P.: Caspian Sea Level from TopexPoseidon altimetry: level now falling, Geophys., Res., Lett., 24, 881-884, 1997.

Climatic Research Unit: University of East Anglia, avaiable at: http://www.cru.uea.ac.uk/cru/ data/temperature/crutem4/station-data.htm, last access: 30 August 2012.

Crétaux, J.-F. and Birkett, C.: Lake studies from satellite radar altimetry, C. R. Lake studies from satellite radar altimetry C. R. Geosci., 338, 1098-1112, 2006.

30 Crutzen, P. J.: Geology of mankind, Nature 415, 23, doi:10.1038/415023a, 2002.

Dean Jr., W. E.: Determination of carbonate and organic matter in calcareous sediments and sedimentary rocks by loss on ignition: comparison with other methods, J. Sed. Petrol., 44, 242-248, 1974.

BGD

9, 16663-16704, 2012

\section{Lingulodinium machaerophorum expansion in the Caspian Sea}

S. A. G. Leroy et al.

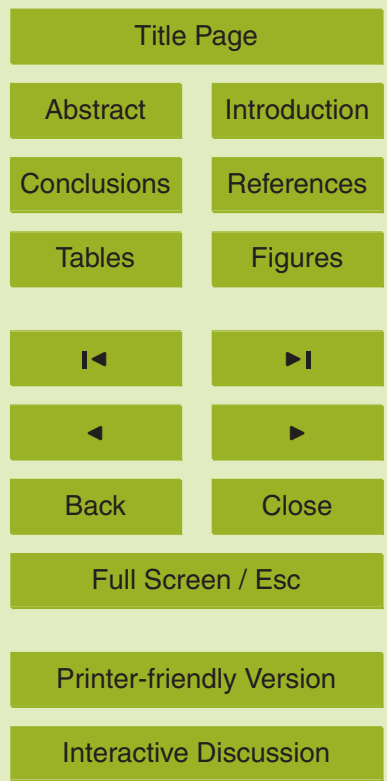


Dee, D. P., Uppala, S. M., Simmons, A. J. et al.:The ERA-Interim reanalysis: configuration and performance of the data assimilation system, Q. J. Roy. Meteor. Soc., 137, 553-597, doi:10.1002/qj.828, 2011.

Deflandre, G. and Cookson, I. C.: Fossil microplankton from Australia late Mesozoic and Tertiary sediments, Aust. J. Mar. Fresh. Res., 6, 242-313, 1955.

Dumont, H. J.: The Caspian Lake: history, biota, structure, and function, Limnol. Oceanogr., 43, 44-52, 1998.

Einsele, G. and Hinderer, M.: Terrestrial yield and the lifetimes of reservoirs, lakes and larger basins, Geol. Rundsch., 86, 288-310, 1997.

10 Firoozfar, A., Bromhead, E. N., Dykes, A. P., and Neshaei, M. A. L.: Southern Caspian Sea coasts, morphology, sediment characteristics, and sea level change, in: Proceedings of the Annual International Conference on Soils, Sediments, Water and Energy, 17,123-150, 2012.

Ghaffari, P., Lahijani, H. A., and Azizpour, J.: Snapshot observation of the physical structure and stratification in deep-water of the South Caspian Sea (western part), Ocean Sci., 6,

15 877-885, doi:10.5194/os-6-877-2010, 2010.

Ginzburg, A. I., Kostianoy, A. G., and Sheremet, N. A.: Sea surface temperature variability, in: The Caspian Sea Environment, edited by: Kostianoy, A. and Kosarev, A., Springer, Berlin, Heidelberg, 59-81, 2005.

Golitsyn, G. S. and Panin, G. N.: The water balance and modern variations of the level of the 20 Caspian Sea, Soviet Meteorol. Hydrol. (English Translation) 1, 46-52, 1989.

Howard, M. D. A., Smith, G. J., and Kudela, R. M.: Phylogenetic relationships of Yessotoxinproducing dinoflagellates, based on the large subunit and internal transcribed spacer ribosomal DNA domains, Appl. Environ. Microbiol., 75, 54-63, 2009.

Jamshidi, S. and BinAbuBakar, N.: Oceanographic study in coastal waters in Babolsar, Asian J. Earth Sci., 4, 1-8, 2011.

Kakroodi, A. A., Kroonenberg, S. B., Hoogendoorn, R. M., Mohammadkhani, H., Yamani, M., Ghasssemi, M. R., and Lahijani, H. A. K.: Rapid Holocene sea-level changes along the Iranian Caspian coast, Quatern. Int., 263, 93-103, 2012.

Kakroodi, A. A., Leroy, S. A. G., Kroonenberg, S. B., Lahijani, H. A. K., Alimohammadian, H., 30 Yamani, M., and Nohegar, A.: Late Pleistocene and Holocene sea level-change and coastal palaeoenvironment along the Iranian Caspian shore, Earth Planet. Sci. Lett., submitted, 2012.

BGD

9, 16663-16704, 2012

\section{Lingulodinium machaerophorum expansion in the Caspian Sea}

S. A. G. Leroy et al.

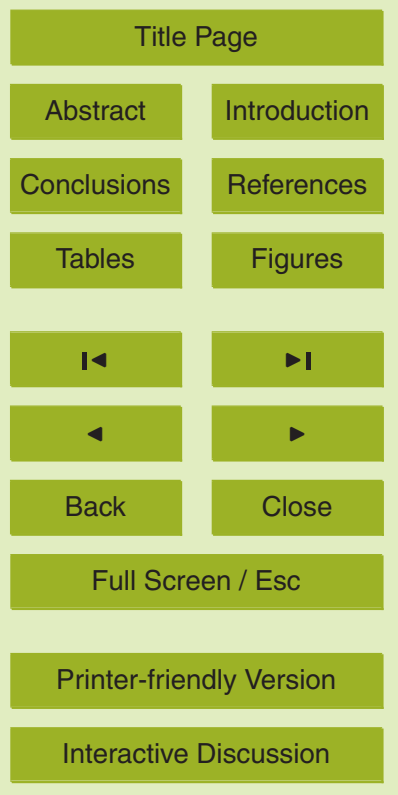


Karbassi, A. R. and Amirnezhad R.: Geochemistry of heavy metals and sedimentation rate in a bay adjacent to the Caspian Sea, Int. J. Environ. Sci. Te., 1, 191-198, 2004.

Kazancı, N., Gulbabazadeh, T., Leroy, S. A. G., and Ileri, O.: Sedimentary and environmental characteristics of the Gilan-Mazenderan plain, Northern Iran: influence of long- and short-

5 term Caspian water level fluctuations on geomorphology, J. Mar. Syst., 46, 145-168, 2004.

Khrustalyov, Y. P. and Artiukhin, Y. V.: Sedimentation in the southern inland seas of the arid zone of the USSR, Mar. Geol., 103, 503-512, 1992.

Kideys, A. E., Roohi, A., Eker-Develi, E., Mélin, F., and Beare, D.: Increased chlorophyll levels in the Southern Caspian Sea following an invasion of jellyfish, Res. Lett. Ecol., 2008, 185642, 10 doi:10.1155/2008/185642, 2008.

Kosarev, A. N.: Physico-geographical conditions of the Caspian Sea, in: The Handbook of Environmental Chemistry, edited by: Hutzinger, O., vol. 5 water pollution, Pt. P, Springer, Berlin, 5-31, 2005.

Kosarev, A. N. and Yablonskaya, E. A.: The Caspian Sea, SPB Academic Publishing, The 15 Hague, 259 pp., 1994.

Kouraev, A. V., Papa, F., Mognard, N. M., Buharizin, P. I., Cazenave, A., Cretaux, J.-F., Dozortseva, J., Remy, F.: Sea ice cover in the Caspian and Aral Seas from historical and satellite data, J. Mar. Syst., 47, 89-100, 2004.

Kroonenberg, S. B., Simmons, M. D., Alekseevski, N. I., Aliyeva, E., Allen, M. B., Aybulatov, D. N., Baba-Zadeh, A., Badyukova, E. N., Davies, C. E., Hinds, D. J., Hoogendoorn, R. M., Huseynov, D., Ibrahimov, B., Mamedov, P., Overeem, I., Rusakov, G. V., Suleymanova, S., Svitoch, A. A., and Vincent, S. J.: Two deltas, two basins, one river, one sea: the modern Volga delta as an analogue of the neogene productive series, South Caspian Basin, river deltas - concepts, models, and examples (SEPM Special Publication No. 83, SEPM Society For Sedimentary Geology), 231-256, 2005.

Kroonenberg, S. B., Abdurakhmanov, G. M., Badyukova, E. N., van der Borg, K., Kalashnikov, A., Kasimov, N. S., Rychagov, G. I., Svitoch, A. A., Vonhof, H. B., and Wesselingh, F. P.: Solar-forced 2600 BP and Little Ice Age highstands of the Caspian Sea, Quatern. Int., 173174, 137-143, 2007.

30 Lahijani, H. and Tavakoli, V.: Identifying provenance of South Caspian coastal sediments using mineral distribution pattern, Quatern. Int., 261, 128-137, 2012.

Lahijani, H. A. K., Tavakoli, V., and Amini, A. H.: South Caspian river mouth configuration under human impact and sea level fluctuations, Environ. Sci., 5, 65-86, 2008.

BGD

9, 16663-16704, 2012

\section{Lingulodinium machaerophorum expansion in the Caspian Sea}

S. A. G. Leroy et al.

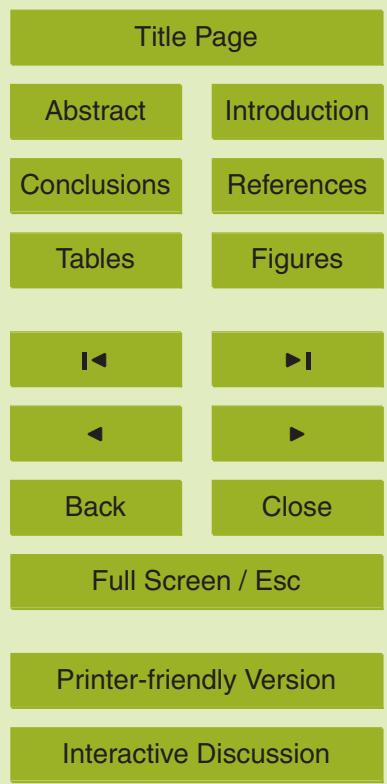


Leroy, S. A. G.: Palaeoenvironmental and palaeoclimatic changes in the Caspian Sea region since the Lateglacial from palynological analyses of marine sediment cores, Geography, Environment, Sustainability, 2, 32-41, 2010.

Leroy, S. A. G., Lahijani, H. A. K., Djamali, M., Naqinezhad, A., Moghadam, M. V., Arpe, K., 5 Shah-Hosseini, M., Hosseindoust, M., Miller, C. S., Tavakoli, V., Habibi, P., Naderi, M.: Late Little Ice Age palaeoenvironmental records from the Anzali and Amirkola lagoons (South Caspian Sea): vegetation and sea level changes, Palaeogeogr. Palaeocl., 302, 415-434, 2011.

Leroy, S. A. G., Marret, F., Giralt, S., and Bulatov, S. A.: Natural and anthropogenic rapid changes in the Kara-Bogaz Gol over the last two centuries by palynological analyses, Quatern. Int., 150, 52-70, 2006.

Leroy, S. A. G., Marret, F., Gibert, E., Chalié, F., Reyss, J.-L., and Arpe, K.: River inflow and salinity changes in the Caspian Sea during the last 5500 years, Quatern. Sci. Rev., 26, 3359-3383, 2007.

Lewis J. and Hallett R: Lingulodinium polyedrum (Gonyaulax polyedra) a blooming dinoflagellate, Oceanogr. Mar. Biol. Annu. Rev., 35, 97-161, 1997.

Loeblich, A. R. and Tappan, H.: Foraminiferal Genera and their Classification, Van Nostrand Reinhold, New York, 1182 pp., 1987.

Londeix, L., Herreyre, Y., Turon, J.-L., and Fletcher, W.: Last Glacial to Holocene hydrology of 20 the Marmara Sea inferred from a dinoflagellate cyst record, Rev. Palaeobot. Palyno., 158, 52-71, 2009.

Makhlough, A., Nasrollahzadeh, H. S., Pourgholam, R., and Rahmati, R.: The Introduction of toxic and harmful new species of phytoplankton in the Iranian costal water of the Southern Caspian Sea, J. Biol. Sci. Lahijan, 5, 77-93, 2011 (in Persian).

Marret, F. and Zonneveld, K. A. F.: Atlas of modern organic-walled dinoflagellate cyst distribution, Rev. Palaeobot. Palyno., 125, 1-200, 2003.

Marret, F., Leroy, S., Chalié, F., and Gasse, F.: New organic-walled dinoflagellate cysts from recent sediments of Central Asian seas, Rev. Palaeobot. Palyno., 129, 1-20, 2004.

Marret, F., Mudie, P., Aksu, A., and Hiscott, R. N.: A Holocene dinocyst record of a two-step 30 transformation of the Neoeuxinian brackish water lake into the Black Sea, Quatern. Int., 197, 72-86, 2009.

\section{BGD}

9, 16663-16704, 2012

\section{Lingulodinium machaerophorum expansion in the Caspian Sea}

S. A. G. Leroy et al.

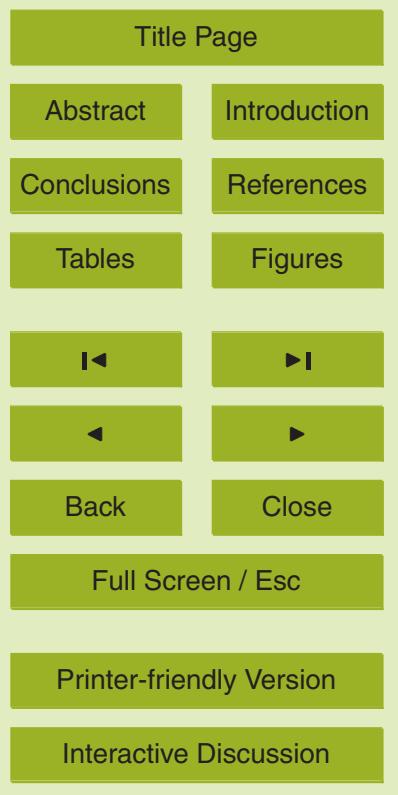


McCarthy, F. M. G. and Mudie, P. J.: Oceanic pollen transport and pollen: dinocyst ratios as markers of late Cenozoic sea level change and sediment transport, Palaeogeogr., Palaeocl., 138, 187-206, 1998.

Mertens, K., Ribeiro, S., Bouimetarhan, I. et al.: Process length variation in cysts of a dinoflag5 ellate, Lingulodinium machaerophorum, in surface sediments: investigating its potential as salinity proxy, Mar. Micropaleontol., 70, 54-69, 2009.

Mudie, P. J., Leroy, S. A. G., Marret, F., Gerasimenko, N., Kholeif, S. E. A., Sapelko, T., and Filipova-Marinova, M.: Non-Pollen Palynomorphs: Indicators of Salinity and Environmental Change in the Caspian-Black Sea-Mediterranean Corridor. in Geology and Geoarchaeology of the Black Sea Region: Beyond the Flood Hypothesis, edited by: Buynevich, I., YankoHombach, V., Gilbert, A. S., and Martin, R. E., Geological Society of America Special Paper, 473, 89-115, 2011.

Nadirov, R. S., Bagirov, E., Tagiyev, M., and Lerche, I.: Flexural plate subsidence, sedimentation rates, and structural development of the super-deep South Caspian Basin, Mar. Petrol. Geol.,

15 14, 383-400, 1997.

NASA: available at: http://data.giss.nasa.gov/gistemp/, last access: 30 August 2012.

Nasrollahzadeh, H. S., Din, Z. B., Foong, S. Y., and Makhlough, A.: Trophic status of the Iranian Caspian Sea based on water quality parameters and phytoplankton diversity, Cont. Shelf Res., 28, 1153-1165, 2008a.

20 Nasrollahzadeh, H. S., Din, Z. B., Foong, S. Y., and Makhlough, A.: Spatial and temporal distribution of macronutrients and phytoplankton before and after the invasion of the ctenophore, Mnemiopsis leidyi, in the Southern Caspian Sea, Chem. Ecol., 24, 233-246, 2008b.

Nasrollahzadeh, H. S., Maklough, A., Pourgholam, R., Vahedi, F., Qanqermeh, A., and Foong, S. Y.: The study of Nodularia spumigena bloom event in the Southern Caspian Sea, Appl. Ecol. Environ. Res., 9, 141-155, 2011.

Omrani Rekavandi, H., Sauer, E. W., Wilkinson, T., Safari Tamak, E., Ainslie, R., Mahmoudi, M., Griffiths, S., Ershadi, M., Jansen Van Rensburg, J., Fattah, M., Ratcliffe, J., Nokandeh, J., Nazifi, A., Thomas, R., Gale, R., and Hoffmann, B.: An Imperial frontier of the Sasanian Empire: further fieldwork at the great wall of Gorgan, Iran, 45, 95-136, 2007.

30 Patimar, R.: Fish species diversity in the lakes of Alma-Gol, Adji-Gol, and Ala-Gol, Golestan province, Northern Iran, J. Ichthyol., 48, 911-917, 2008.

\section{BGD}

9, 16663-16704, 2012

\section{Lingulodinium machaerophorum expansion in the Caspian Sea}

S. A. G. Leroy et al.

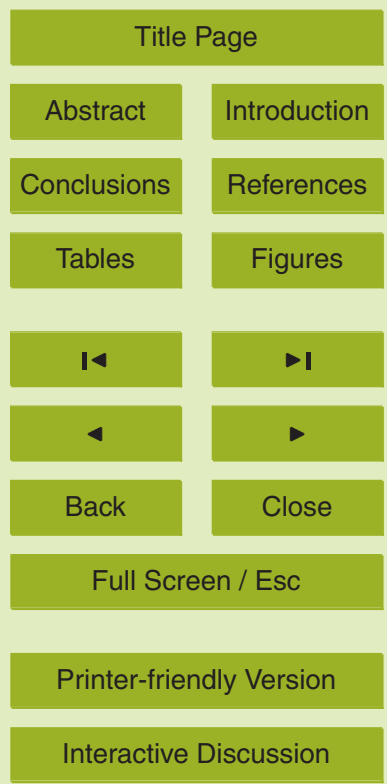


Patimar, R., Yousefi, M., and Hosieni, S. M.: Age, growth and reproduction of the sand smelt Atherina boyeri Risso, 1810 in the Gomishan wetland - Southeast Caspian Sea, Estuar. Coast. Shelf S., 81, 457-462, 2009.

Pierret, M. C., Chabaux, F., Leroy, S. A. G., and Causse, C.: A record of Late Quaternary continental weathering in the sediment of the Caspian Sea: evidence from U-Th, Sr isotopes, trace element and palynological data, Quatern. Sci. Rev., 51, 40-55, 2012.

Reyss, J.-L., Schmidt, S., Legeleux, F., and Bonte, P.: Large, low background well-type detectors for measurements of environmental radioactivity, Nucl. Instrum. Meth. A, 357, 391-397, 1995.

10 Schumacher, B. A.: Methods for the Determination of Total Organic Carbon (TOC) in Soils and Sediments, US Environmental Protection Agency, Las Vegas, NV, 2002.

Sgarrella, F. and Moncharmont Zei, M.: Benthic foraminifera of the Gulf of Naples (Italy): systematic and autoecology, Boll. Soc. Paleontol. I., 32, 145-264, 1993.

Soloviev, D.: Identification of the extent and causes of Cyanobacterial bloom in September-October 2005 and development of the capacity for observation and prediction of HAB in the Southern Caspian Sea using Remote Sensing Technique, available at: http://www.caspianenvironment.org/newsite/DocCenter/2006/HABrepFinalFull_ corrected_compressed_pictures.doc, 2005, last access: 23 June 2012.

Tagiyev, M. F., Nadirov, R. S., Bagirov, E. B., and Lerche, I.: Geohistory, thermal history and 20 hydrocarbon generation history of the North-west South Caspian basin, Mar. Petrol. Geol., 14, 363-382, 1997.

Tuzhilkin, V. S. and Kozarev, A. N.: in The Caspian Sea environment, edited by: Kostianoy, A. and Kosarev, A., Springer Berlin, Heidelberg, 33-57, 2005.

USDA: avaiable at: http://www.pecad.fas.usda.gov/cropexplorer/global_reservoir/gr_regional_ chart.cfm? regionid $=$ metu $\backslash$ \&region $=\backslash \&$ reservoir $\_$name $=$Caspian, last access: 30 August 2012.

Verleye, T., Mertens, K. N., Louwye, S., and Arz, H. W.: Holocene Salinity changes in the Southwestern Black Sea: a reconstruction based on dinoflagellate cysts, Palynology, 33, 77-100, 2009.

30 Voronina, E., Polyak, L., de Vernal, A., and Peyron, O.: Holocene variations of sea-surface conditions in the Southeastern Barents Sea, reconstructed from dinoflagellate cyst assemblages, J. Quatern. Sci., 16, 7, 717-726, 2001.

\section{BGD}

9, 16663-16704, 2012

\section{Lingulodinium machaerophorum expansion in the Caspian Sea}

S. A. G. Leroy et al.

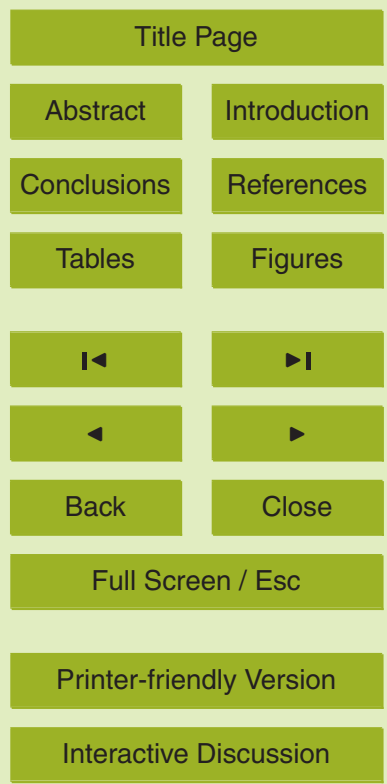


Voropayev, G. V., Kransnozhon, G. F., and Lahijani, H.: Riverine sediments and stability of Iranian coast of the Caspian Sea, Water Resour., 25, 747-758, 1998.

Zaker, N. H., Ghaffari, P., and Jamshidi, S.: Physical study of the southern coastal waters of the Caspian Sea, off Babolsar, Mazandaran, Iran, J. Coastal Res., 50, 564-569, 2007.

5 Zaker, N. H., Ghaffari, P., Jamshidi, S., and Nouranian, M.: Currents on the Southern Continental Shelf of the Caspian Sea off Babolsar, Mazandaran, Iran, J. Coastal Res., 64, 1989-1997, 2011.

Zenkevitch, L. A.: Biology of the Seas of the USSR, George Allen and Unwin Ltd, London, 1963.

\section{BGD}

9, 16663-16704, 2012

\section{Lingulodinium machaerophorum expansion in the Caspian Sea}

S. A. G. Leroy et al.

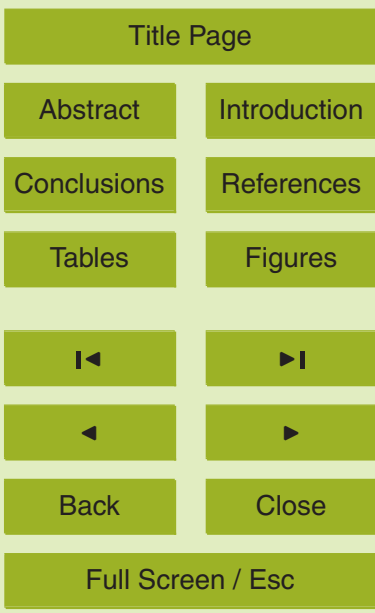

Printer-friendly Version

Interactive Discussion 
Table A1. Location of surface samples for dinocysts according to increasing values of L. machaerophorum B. ${ }^{1}$ Kazanciet al. (2004); ${ }^{2}$ Leroy et al. (2006). n/a: not available.

\begin{tabular}{|c|c|c|c|c|c|c|c|c|c|c|}
\hline Label & lat $\mathrm{N}$ & long $\mathrm{E}$ & $\begin{array}{l}\text { water } \\
\text { depth } \\
\text { in } \mathrm{m}\end{array}$ & Location brief description & $\begin{array}{c}\text { Sampling } \\
\text { date }\end{array}$ & $\begin{array}{l}\text { Type } \\
\text { of } \\
\text { sample }\end{array}$ & $\begin{array}{l}\text { Surface } \\
\text { temperatur } \\
\text { e in C }\end{array}$ & $\begin{array}{l}\text { Surface } \\
\text { salinity }\end{array}$ & Date of measurements \& source & $\begin{array}{l}\text { Published } \\
\text { palynologic } \\
\text { al sample } \\
\text { label }\end{array}$ \\
\hline Almagol & $\begin{array}{l}3725 \\
53.50\end{array}$ & 543852.18 & 0,6 & $\begin{array}{l}\text { core top in Modern Lagoon, } \\
\text { water at zero }\end{array}$ & Sept. 2010 & lagoon & $11-28$ & $2-3$ & $\begin{array}{l}\text { not measured at sampling; Patimar (2008) for 2000- } \\
\qquad 2002\end{array}$ & \\
\hline Alagol & $\begin{array}{l}3721 \\
59.48\end{array}$ & 543444.33 & 0,6 & $\begin{array}{l}\text { core top in Modern Lagoon, } \\
\text { water at }-6 \mathrm{~m}\end{array}$ & Sept. 2010 & lagoon & $10-27$ & $3.5-4.0$ & $\begin{array}{l}\text { not measured at sampling; Patimar (2008) for 2000- } \\
\qquad 2002\end{array}$ & \\
\hline Anzalio9 & 372656.6 & 492249.8 & 1,8 & grab HCGA09, $280 \mathrm{~m}$ away & 26 June 2008 & 8 lagoon & n/a & $\mathrm{n} / \mathrm{a}$ & not measured at sampling & \\
\hline Anzali 6 & 37251.94 & 492517.93 & c. $1-2$ & grab Anzali Lagoon surface & 1995 & lagoon & $4.5-27.5$ & $0.8-3.0$ & not measured at sampling; but across $2000^{1}$ & Ens8 ${ }^{1}$ \\
\hline US24 & 431914 & 490602 & 61 & core top & Aug. 1994 & marine & 25,5 & 9.5 & F. Chalié, snapshot & \\
\hline US02 & 3916 & 5128 & 315 & $\begin{array}{l}\text { core top, SR9406US14, } \\
\text { SR01US9402, at } 0.5 \mathrm{~cm} \text { depth }\end{array}$ & Aug. 1994 & marine & 24,7 & 10.9 & F. Chalié, snapshot & $\mathrm{USO}^{2}$ \\
\hline Anzali 3 & 37295.62 & 491914.05 & c. $1-2$ & grab Anzali Lagoon surface & 1995 & lagoon & $4.5-27.5$ & $0.5-4.5$ & not measured at sampling; but across $2000^{1}$ & Ens $15^{1}$ \\
\hline Anzali 100 & 3736 & 4932 & 100 & grab for phytoplankton & Jan. 2011 & marine & $9.3-30$ & $7-11$ & H. S. Nasrollahzadeh, annual & \\
\hline $\begin{array}{l}\text { Astara20 } \\
\text { W }\end{array}$ & 3824 & 4901 & 20 & grab for phytoplankton & Winter 2010 & marine & $7.5-33$ & $7.5-14$ & H. S. Nasrollahzadeh, annual & \\
\hline $\begin{array}{l}\text { Torkman2 } \\
0\end{array}$ & 3705 & 5335 & 20 & grab for phytoplankton & Winer 2010 & marine & $?-29.5$ & $9-10$ & H. S. Nasrollahzadeh, annual & \\
\hline US01 & 384410 & 531115 & 13 & $\begin{array}{l}\text { core top, SR9403US09, } \\
\text { SR01US9401, at } 0.5 \mathrm{~cm} \text { depth }\end{array}$ & Aug. 1994 & marine & 28 & 10.5 & F. Chalié, snapshot & \\
\hline $\operatorname{cs} 10$ & 364825.0 & 523302.8 & 250 & core top, core $\mathrm{CS} 10$ at $2 \mathrm{~cm}$ & 2007 & marine & 18 & 12 & $\begin{array}{l}\text { not measured at sampling, but snapshot for a station } \\
\text { with } 42 \mathrm{~m} \text { water depth in Nov. 2008 (Jamshidi \& } \\
\text { BinAbuBakar 2011) }\end{array}$ & \\
\hline Astara 100 & 3822 & 4908 & 100 & grab for phytoplankton & $\begin{array}{l}\text { Summer } \\
2010\end{array}$ & marine & $7.8-32.4$ & $7-12$ & H. S. Nasrollahzadeh, annual & \\
\hline $\begin{array}{l}\text { Astara } \\
20 S\end{array}$ & 3824 & 4901 & 20 & grab for phytoplankton & $\begin{array}{l}\text { Summer } \\
2010\end{array}$ & marine & $7.5-32.6$ & $7.5-14$ & H. S. Nasrollahzadeh, annual & \\
\hline Babol100 & 3649 & 5239 & 100 & $\begin{array}{l}\text { grab for phytoplankton, } \\
\text { babolsar }\end{array}$ & Jan. 2011 & marine & $9.6-28$ & $9.5-13$ & H. S. Nasrollahzadeh, annual & \\
\hline US26 & 431936 & 490558 & 61 & core top & Aug. 1994 & marine & 25,5 & 9.5 & F. Chalié, snapshot & \\
\hline $\operatorname{cs} 03$ & $37^{\circ} 3528.3$ & 493416.6 & 250 & core top, core CS03 at $2 \mathrm{~cm}$ & 2007 & marine & 10 & 12 & $\begin{array}{l}\text { not measured at sampling, but for a station nearby } \\
\text { in } 2008 \text { (Ghaffari et al. 2010; S. Haghani) }\end{array}$ & \\
\hline Anzali 4 & $\begin{array}{l}3725 \\
18.16\end{array}$ & 492648.36 & c. $1-2$ & grab Anzali Lagoon surface & 1995 & lagoon & $4.5-27.5$ & $1.0-5.0$ & not measured at sampling; but across $2000{ }^{1}$ & Ens6 ${ }^{1}$ \\
\hline Anzali 20 & 3730 & 4929 & 20 & grab for phytoplankton & Jan. 2011 & marine & $7-32$ & $7-10$ & H. S. Nasrollahzadeh, annual & \\
\hline Anzali 2 & $\begin{array}{l}3727 \\
40.01\end{array}$ & $\begin{array}{l}4922 \\
11.41\end{array}$ & c. $1-2$ & grab Anzali Lagoon surface & 1995 & lagoon & $4.5-27.5$ & $0.5-1.0$ & not measured at sampling; but across $2000^{1}$ & Ens $12^{1}$ \\
\hline Babol20 & 3646 & 5240 & 20 & $\begin{array}{l}\text { grab for phytoplankton, } \\
\text { Babolsar }\end{array}$ & Jan. 2011 & marine & $10-29.4$ & $8-11.4$ & H. S. Nasrollahzadeh, annual & \\
\hline Anzali 1 & $\begin{array}{l}3724 \\
55.24\end{array}$ & 49299.12 & c. $1-2$ & grab Anzali Lagoon surface & 1995 & lagoon & $4.5-27.5$ & $0.6-2.0$ & not measured at sampling; but across $2000^{1}$ & Ens $1^{1}$ \\
\hline $\begin{array}{l}\text { BTorkman } \\
2\end{array}$ & 365357.3 & 540246.1 & c. 0.1 & $\begin{array}{l}\text { artificial pool behind bay, } \\
\text { salinity 22, reeds, Salicornia }\end{array}$ & 20 May 2011 & lagoon & n/a & 22 & S. Leroy, snapshot & \\
\hline $\begin{array}{l}\text { BTorkman } \\
1\end{array}$ & 365349.7 & 540239.4 & c. 0.1 & $\begin{array}{l}\text { harbour, salinity } 17, \text { mud with } \\
\text { Salicornia meadow }\end{array}$ & 20 May 2011 & lagoon & n/a & 17 & S. Leroy, snapshot & \\
\hline TR1 & $\begin{array}{l}3703 \\
43.70\end{array}$ & 540159.02 & 0,1 & $\begin{array}{l}\text { core top in Modern Lagoon, } \\
\text { water at }-28 \mathrm{~m}, \mathrm{Gm} 1 \text { short }\end{array}$ & Sept. 2010 & lagoon & $9-30$ & $20-24$ & Spring-Summer in 2007 (Patimar et al. 2009) & \\
\hline AS17 & 463104 & 604155 & 12,5 & core top, AS17-5 at $0.5 \mathrm{~cm}$ & 17 June 1999 & marine & $n / a$ & 22 & $\begin{array}{c}\text { (Boomer et al. 2003; S. Juggins pers. comm.) } \\
\text { snapshot }\end{array}$ & ASO. $5^{2}$ \\
\hline KBG08-01 & 4151 & 5315 & 0,8 & $\begin{array}{l}\text { core top, KBG08-01 at } 0.5 \mathrm{~cm} \\
\text { denth }\end{array}$ & 1999 & marine & $-3.5-+33$ & $170-250$ & $1999^{2}$ & KBG08-01 ${ }^{2}$ \\
\hline
\end{tabular}

BGD

9, 16663-16704, 2012

\section{Lingulodinium machaerophorum expansion in the Caspian Sea}

S. A. G. Leroy et al.

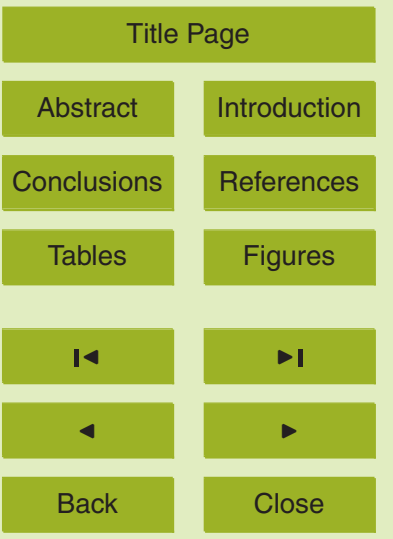

Full Screen / Esc

Printer-friendly Version

Interactive Discussion 


\section{BGD}

9, 16663-16704, 2012

Table A2. Core numbering and location. Note: locations and water depths for the two Usnel cores are approximate owing to poor weather conditions and navigation tool performances.

\begin{tabular}{llllll}
\hline $\begin{array}{l}\text { Full name } \\
\text { General location }\end{array}$ & Short name & Length $(\mathrm{cm})$ & $\begin{array}{l}\text { Latitude N Lon- } \\
\text { gitude E }\end{array}$ & $\begin{array}{l}\text { Water } \\
\text { depth } \\
(\mathrm{m})\end{array}$ & $\begin{array}{l}\text { Date } \\
\text { Corer }\end{array}$ \\
\hline $\begin{array}{l}\text { On board } \\
\text { no SR9403US09 }\end{array}$ & US01 & 36 & $38^{\circ} 44^{\prime} 10^{\prime \prime}$ & 13 & $\begin{array}{l}1994 \\
\text { Usnel } \\
\text { box }\end{array}$ \\
$\begin{array}{l}\text { Museum } \\
\text { no SR01US9401 }\end{array}$ & & $53^{\circ} 11^{\prime} 15^{\prime \prime}$ & & \\
$\begin{array}{l}\text { Off shore Turk- } \\
\text { menistan }\end{array}$ & & & & & \\
\hline $\begin{array}{l}\text { On board } \\
\text { no SR9406US14 }\end{array}$ & US02 & 57 & $39^{\circ} 16^{\prime}$ & 315 & 1994 \\
$\begin{array}{l}\text { Museum } \\
\text { no SR01US9402 }\end{array}$ & & $51^{\circ} 28^{\prime}$ & & $\begin{array}{l}\text { Usnel } \\
\text { box }\end{array}$ \\
$\begin{array}{l}\text { Centre of south } \\
\text { basin }\end{array}$ & & & & & \\
\hline $\begin{array}{l}\text { CS07-03 } \\
\text { Off shore Anzali }\end{array}$ & CS03 & 166 & $37^{\circ} 35^{\prime} 28.3^{\prime \prime}$ & 250 & $\begin{array}{l}2007 \\
\text { Piston }\end{array}$ \\
\hline $\begin{array}{l}\text { CS07-10 } \\
\text { Off shore Babol- } \\
\text { sar }\end{array}$ & CS10 & 147 & $36^{\circ} 48^{\prime} 25.0^{\prime \prime}$ & 250 & $\begin{array}{l}2007 \\
\text { Piston }\end{array}$ \\
\hline
\end{tabular}

\section{Lingulodinium machaerophorum expansion in the Caspian Sea}

S. A. G. Leroy et al.

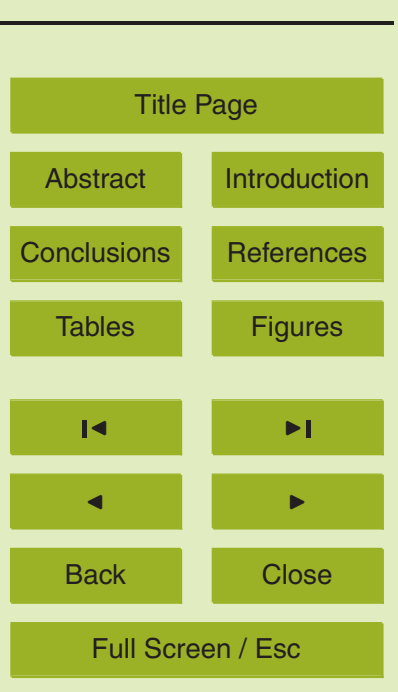

Printer-friendly Version

Interactive Discussion 

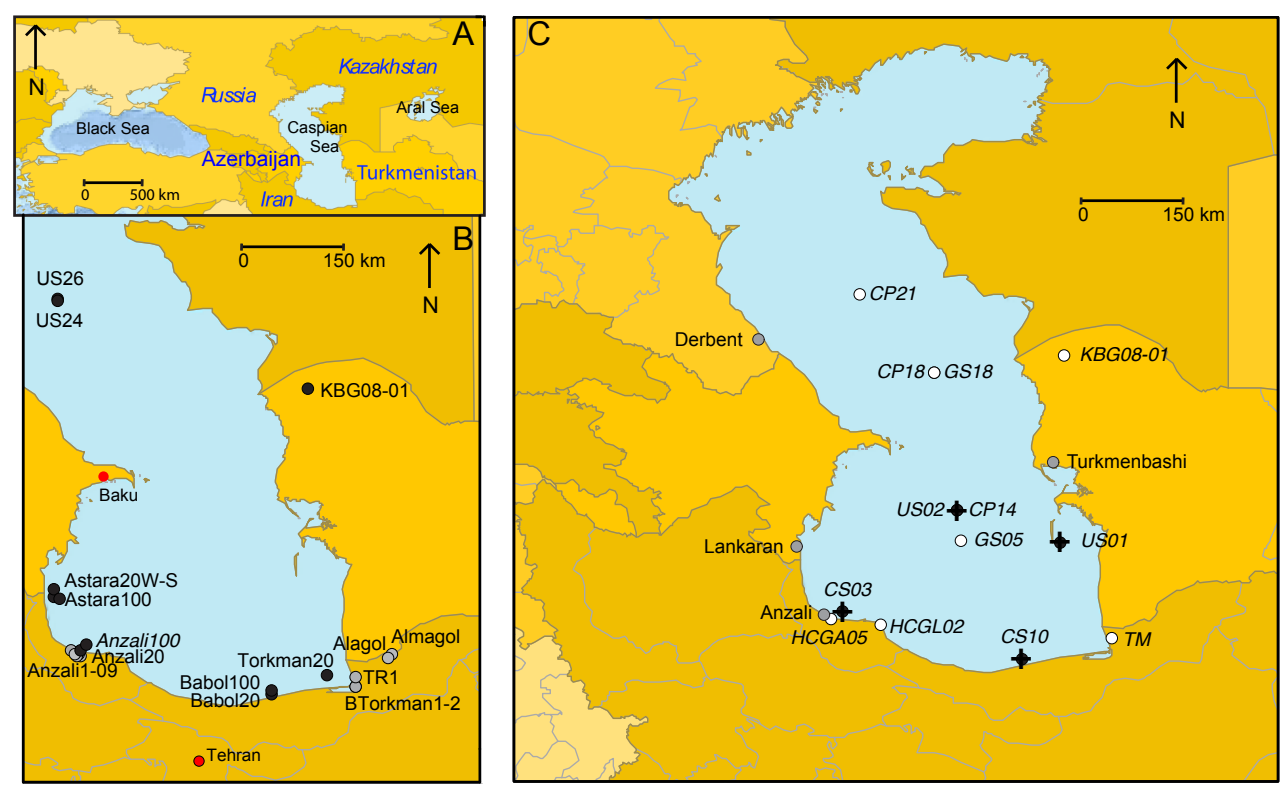

Fig. 1. Location maps. (A): Location of the Caspian Sea at the boarder between Europe and Asia. (B): Location of the surface samples in the Caspian Sea (black dots for marine samples and grey dots for lagoonal samples), and capital cities (red dots). (C): Location of the four short cores (black dots with cross), the other Caspian cores (white dots) and the meteorological stations (gray dots).

\section{BGD}

9, 16663-16704, 2012

\section{Lingulodinium machaerophorum expansion in the Caspian Sea}

S. A. G. Leroy et al.

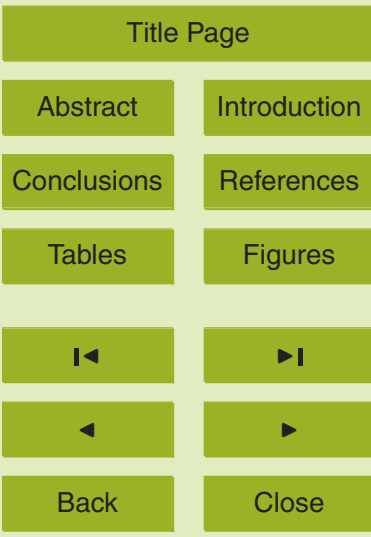

Full Screen / Esc

Printer-friendly Version

Interactive Discussion 

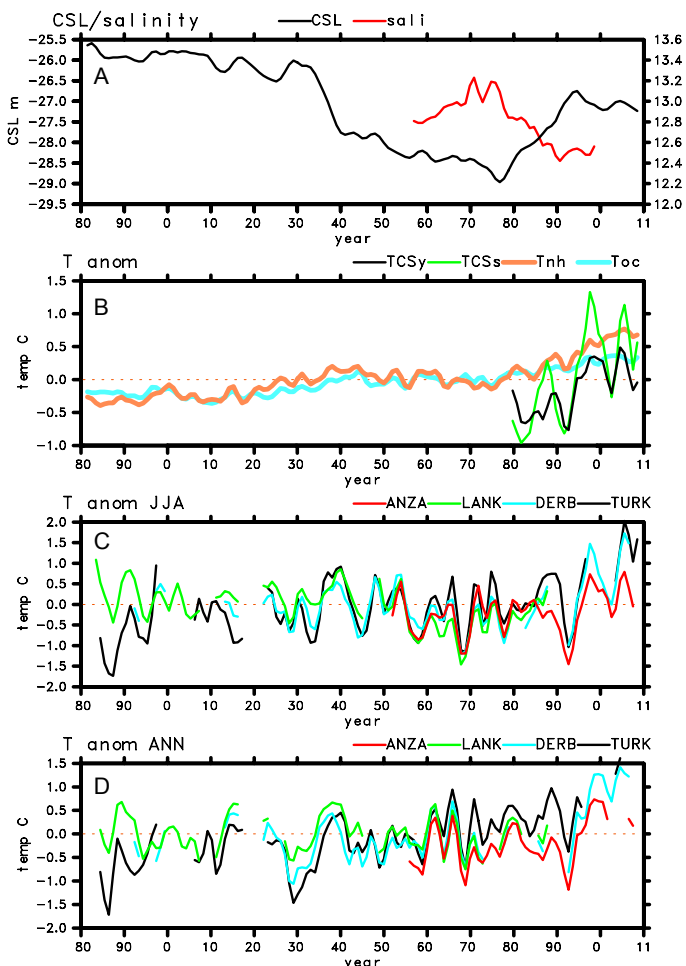

Fig. 2. Selected oceanographic and meteorological data for the Caspian Sea. All data are smoothed with a 1-2-1 filter. Anomalies are used for panels (B), (C) and (D). (A) Caspian Sea level (CSL) (Cazenave et al., 1997; Golitsyn and Panin, 1989; USDA, 2012) and summer surface salinity from the centre of the middle basin (sali) (Tuzhilkin and Kosarev, 2005). (B) sea surface temperatures of Southern Caspian Sea from analysis (TCSy = CS year-JanuaryDecember; TCSs = CS summer-JJA.) (Dee et al., 2011); annual mean $2 \mathrm{~m}$ temperatures of the Northern Hemisphere (Tnh) and annual mean of global ocean temperatures (Toc) (NASA, 2012). (C) $2 \mathrm{~m}$ temperatures in summer (JJA) for the following meteorological stations (Climatic Research Unit, University of East Anglia, 2012): ANZA $=407180,37.5^{\circ} \mathrm{N}$ 49.5E, -26 ma.s.I., Anzali, Iran LANK $=379850,38.7^{\circ} \mathrm{N} 48.8^{\circ} \mathrm{E},-12$ ma.s.I., Lankaran, Azerbaijan DERB $=374700$, $42.0^{\circ} \mathrm{N} 48.3^{\circ} \mathrm{E},-19$ ma.s.I., Derbent, Russia TURK $=385070,40.1^{\circ} \mathrm{N} 53.0^{\circ} \mathrm{E}, 82 \mathrm{ma}$.s.l., Turkmenbashi, Turkmenistan (D) annual $2 \mathrm{~m}$ temperatures for stations in $2^{\circ} \mathrm{C}$ (Climatic Research Unit, University of East Anglia, 2012).
BGD

9, 16663-16704, 2012

\section{Lingulodinium machaerophorum expansion in the Caspian Sea}

S. A. G. Leroy et al.

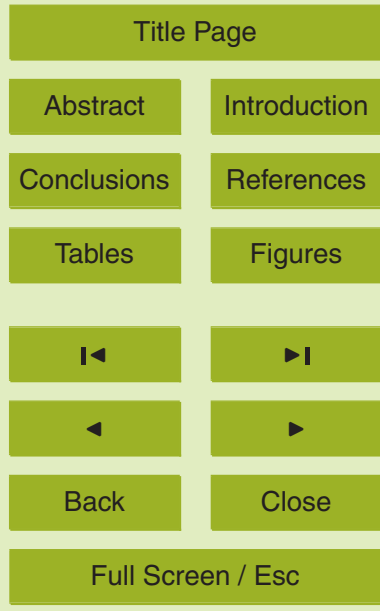

Printer-friendly Version

Interactive Discussion 
BGD

9, 16663-16704, 2012

\section{Lingulodinium machaerophorum expansion in the Caspian Sea}

S. A. G. Leroy et al.

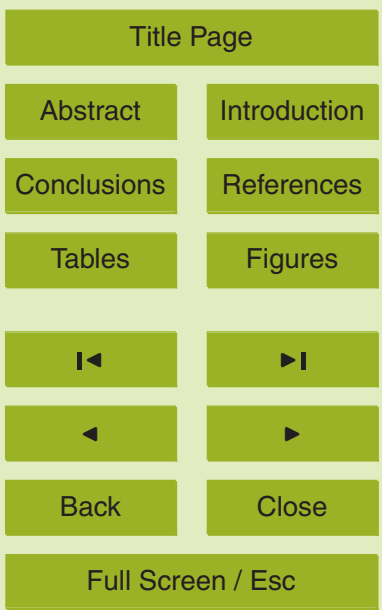

Printer-friendly Version

Interactive Discussion 


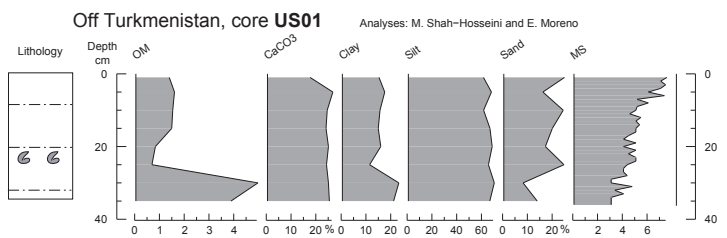

\section{BGD}

9, 16663-16704, 2012

\section{Lingulodinium machaerophorum expansion in the Caspian Sea}

S. A. G. Leroy et al.
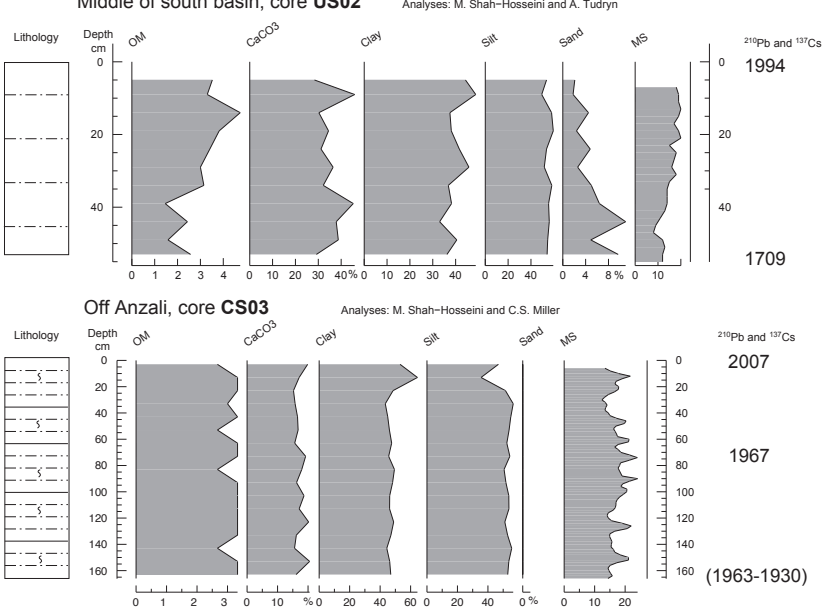

Title Page

Abstract

Introduction

Conclusions

References

Tables

Figures

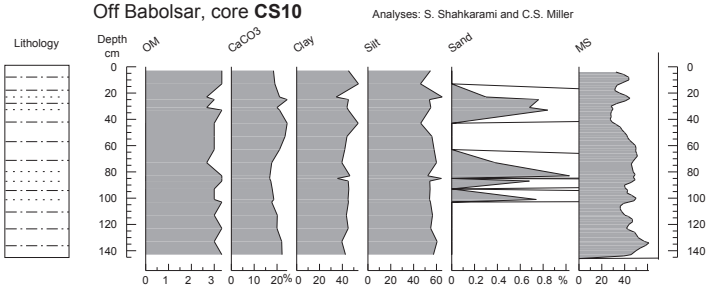

Fig. 4. Sedimentology of the four short cores: visual description of the lithology, organic matter $(\mathrm{OM})$ and calcium carbonate $\left(\mathrm{CaCO}_{3}\right)$ contents in percentages after Loss-On-Ignition, clay, silt and sand percentages by particle size analysis, as well as magnetic susceptibility (MS).

\section{4}

4

Back

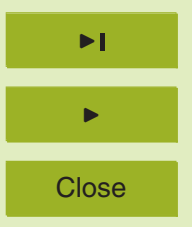

Full Screen / Esc

Printer-friendly Version

Interactive Discussion 
BGD

9, 16663-16704, 2012

\section{Lingulodinium machaerophorum expansion in the Caspian Sea}
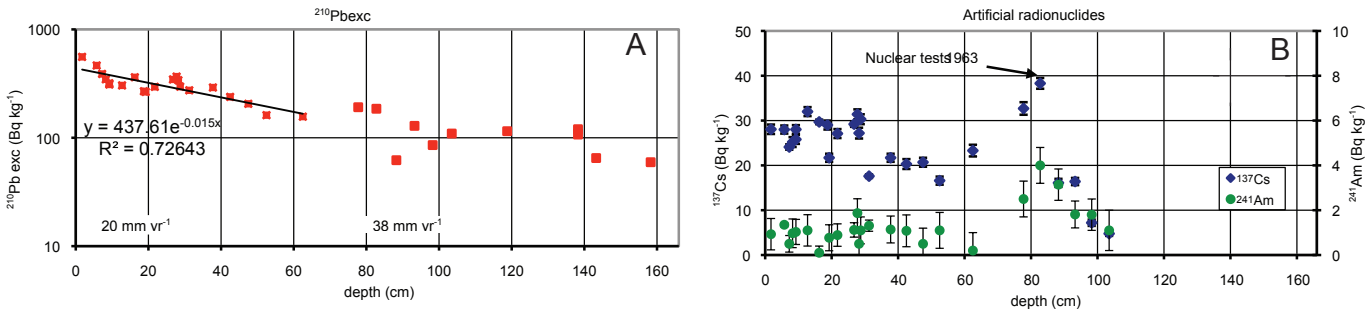

Fig. 5. Radionuclide dating of core CS03. (A) Profiles of ${ }^{210} \mathrm{Pbexc}$. Activities ( $\mathrm{Bq} \mathrm{kg}^{-1}$, dry weight) with depth in $\mathrm{cm}$. The regression line between the top and $65 \mathrm{~cm}$ depth corresponds to an average sedimentation rate of $2.0 \mathrm{~cm} \mathrm{yr}^{-1}$. Deeper in the core the regression line corresponds to $3.8 \mathrm{~cm} \mathrm{yr}^{-1}$. (B) Profiles of artificial radionuclides ${ }^{137} \mathrm{Cs}$ and ${ }^{241} \mathrm{Am}$ activities (fallout from nuclear weapon testing) with depth in $\mathrm{cm}$. The maximum activity at $83 \mathrm{~cm}$ depth for both nuclides corresponds to the maximum global fallout peak in 1963.
S. A. G. Leroy et al.

\section{Title Page}

\section{Abstract}

Introduction

Conclusions

References

Tables

Figures

14

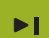

4

Back

Close

\section{Full Screen / Esc}

Printer-friendly Version

Interactive Discussion 


\section{BGD}

off Turkmenistan, core US01

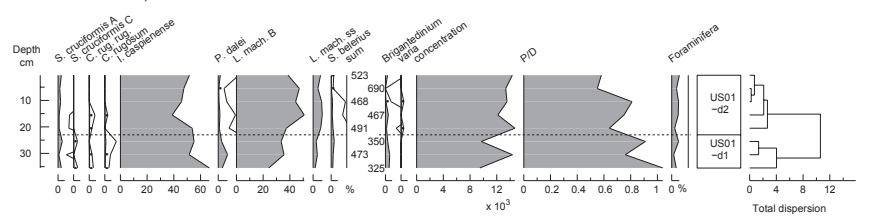

centre, core US02

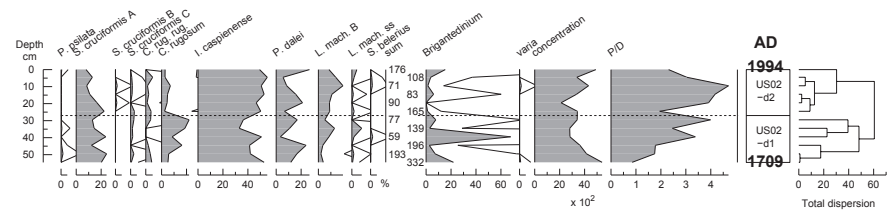

off Anzali, core $\mathrm{CSO} 3$

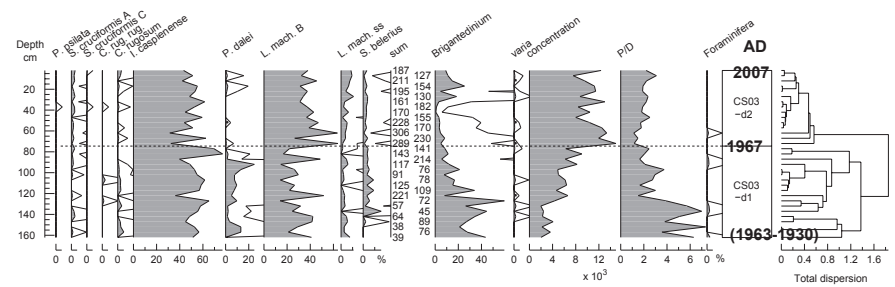

off Babolsar, core CS10

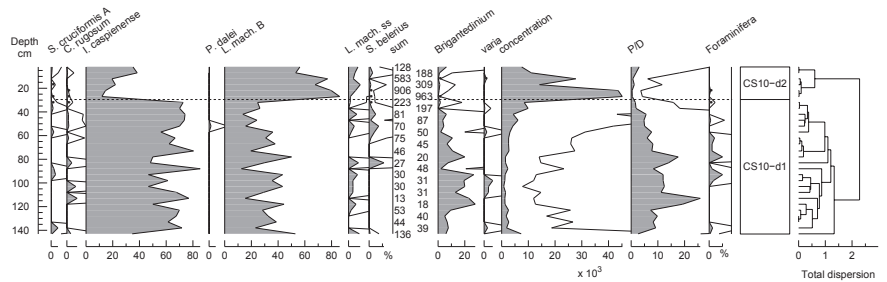

Fig. 6. Dinocyst diagrams of cores US01, US02, CS03 and CS10, taken in the south basin of the Caspian Sea. Concentration in numbers of dinocysts $\mathrm{ml}^{-1}$ of wet sediment. With $10 x$ exaggeration curve. To the right dendrograms used for the zonation.
9, 16663-16704, 2012

\section{Lingulodinium machaerophorum expansion in the Caspian Sea}

S. A. G. Leroy et al.

\section{Title Page}

\section{Abstract}

Introduction

Conclusions

References

Tables

Figures

14

$>$ I

Back

Close

\section{Full Screen / Esc}

Printer-friendly Version

Interactive Discussion 


\section{Lingulodinium machaerophorum percentages}

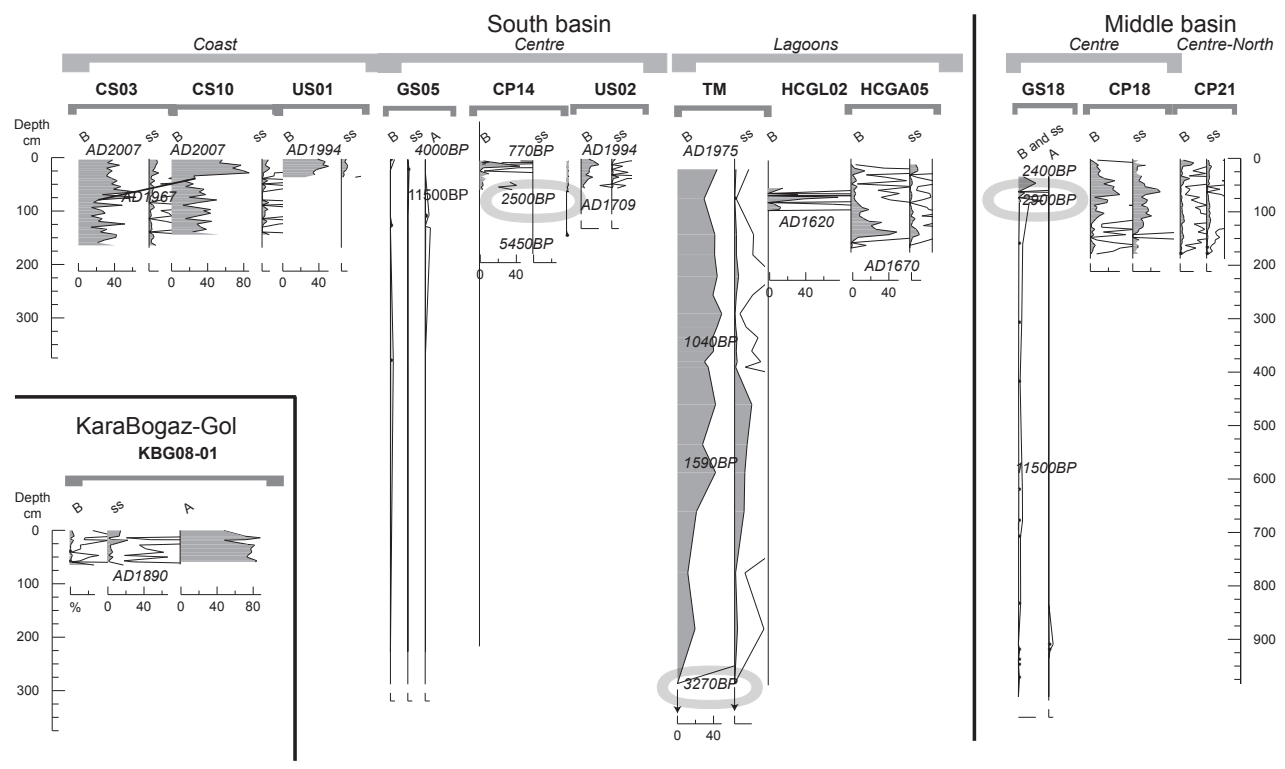

Fig. 7. The three forms of Lingulodinium machaerophorum in thirteen cores of the Caspian Sea over the last few millennia. The three grey ovals underline the start of the $L$. machaerophorum development. Black dots for values lower than $0.5 \%$. The percentages were calculated for sums excluding Brigantedinium. Core KBG08 (Leroy et al., 2006); cores GS05 and GS18 (Leroy, personal communication, 2012); part of core TM (Kakroodi et al., 2012); cores HCGL02 and HCGA05 (Leroy et al., 2011); cores CP14, CP18 and CP21 (Leroy et al., 2007). The grey circles indicate the start of the $L$. machaerophorum development. B, ss and A are the three forms of L. machaerophorum. Dates in AD or in calibrated years BP. With 10x exaggeration curve.
BGD

9, 16663-16704, 2012

\section{Lingulodinium machaerophorum expansion in the Caspian Sea}

S. A. G. Leroy et al.

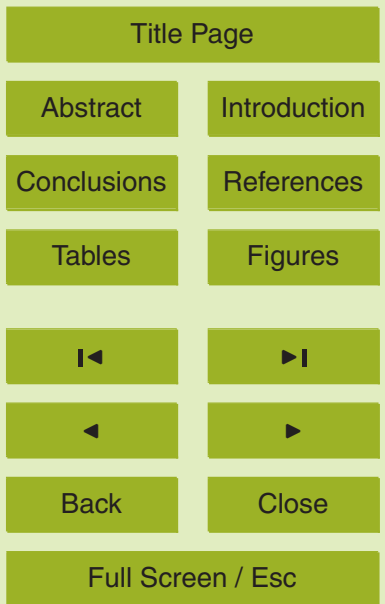

Printer-friendly Version

Interactive Discussion 
BGD

9, 16663-16704, 2012

\section{Lingulodinium machaerophorum expansion in the Caspian Sea}

S. A. G. Leroy et al.

\section{Title Page}

\section{Abstract}

Introduction

Conclusions

References

20

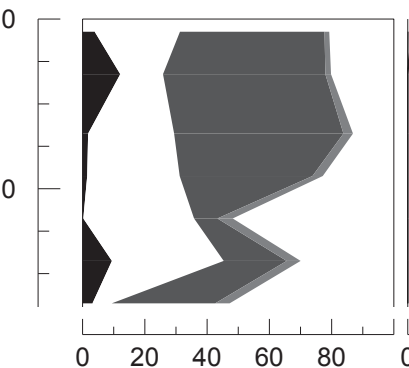

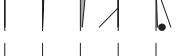
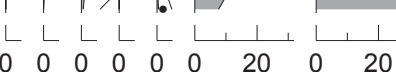

Fig. A1. Foraminifera assemblages of core US01, taken in the south basin of the Caspian Sea. Names with fraction size in $\mu \mathrm{m}$.

Tables

Figures

14

Back

Full Screen / Esc

Printer-friendly Version

Interactive Discussion 